\title{
High-temperature pressure swing adsorption cycle design for sorption-enhanced water- gas shift
}

J. Boon (ECN)

P.D. Cobden (ECN)

H.A.J. van Dijk (ECN)

M. van Sint Annaland (TU/e)

November 2014

ECN-W--14-017 


\title{
High-temperature pressure swing adsorption cycle design for sorption-enhanced water-gas shift
}

\author{
Jurriaan Boon $^{\mathrm{a}, \mathrm{b}, *}$, P.D. Cobden ${ }^{\mathrm{a}}$, H.A.J. van Dijk ${ }^{\mathrm{a}}$, M. van Sint Annaland ${ }^{\mathrm{b}}$ \\ a Sustainable Process Technology, ECN, P.O. Box 1, 1755ZG Petten, The Netherlands \\ ${ }^{\mathrm{b}}$ Chemical Process Intensification, TU/e, P.O. Box 513, 5600MB Eindhoven, The Netherlands
}

\section{H I G H L I G H T S}

- Sorption-enhanced water-gas shift (SEWGS): H2 from syngas in single unit operation.

- SEWGS cycle design based on recently published $\mathrm{CO}_{2}$ and $\mathrm{H}_{2} \mathrm{O}$ interaction with K-HTC.

- Adsorption of steam during rinse enhances $\mathrm{CO}_{2}$ product purity.

- Cycle consumes significantly less steam than previously reported cycle designs.

\section{A R T I C L E I N F O}

\section{Article history:}

Received 7 July 2014

Received in revised form

4 September 2014

Accepted 22 September 2014

Available online 2 October 2014

Keywords:

Sorption-enhanced water-gas shift

Adsorption isotherm

Cycle design

Adsorptive rinse

\section{G R A P H I C A L A B S T R A C T}

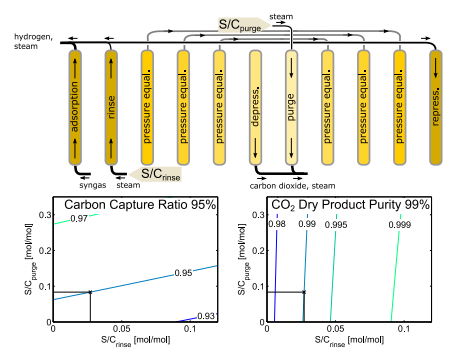

\begin{abstract}
A B S T R A C T
Sorption-enhanced water-gas shift (SEWGS) combines the water-gas shift reaction with in situ adsorption of $\mathrm{CO}_{2}$ on potassium-promoted hydrotalcite (K-HTC) and thereby allows production of hot, high pressure $\mathrm{H}_{2}$ from syngas in a single unit operation. SEWGS is a cyclic process, that comprises high pressure adsorption and rinse, pressure equalisation, and low pressure purge. Here, results are presented of a SEWGS cycle design study, based on recently developed expressions for the interaction of $\mathrm{CO}_{2}$ and $\mathrm{H}_{2} \mathrm{O}$ with K-HTC. It is shown that during the cycle, steam adsorbs in the rinse step and desorbs during the subsequent reduction in pressure, thereby improving the $\mathrm{CO}_{2}$ purity in the column and thus enhancing the efficiency of the rinse. A parameter study based on numerical simulations shows that the carbon capture ratio depends mainly on the purge steam to carbon feed ratio, whereas the $\mathrm{CO}_{2}$ product purity depends mainly on the rinse steam to carbon feed ratio. An optimisation yields a SEWGS cycle that consumes significantly less steam than cycle designs previously reported in the literature.
\end{abstract}

(c) 2014 Elsevier Ltd. All rights reserved.

\section{Introduction}

Against a backdrop of rising atmospheric $\mathrm{CO}_{2}$ concentration, an intensified greenhouse gas effect, and accelerating climate change, political bodies on many levels have expressed commitment to curb $\mathrm{CO}_{2}$ emissions. In line with these ambitions, deployment of

\footnotetext{
* Corresponding author at: Sustainable Process Technology, ECN, P.O. Box 1, 1755ZG Petten, The Netherlands.

E-mail address: boon@ecn.nl (J. Boon).
}

renewable energy is increasing rapidly, energy efficiency is being improved, and in parts of the world gas is replacing coal in power generation. Nevertheless, in a striking contrast energy related $\mathrm{CO}_{2}$ emissions continue to increase, reaching a record high of $31.6 \mathrm{Gt}$ in 2012 due to the steady increase in fossil fuel consumption (Birol, 2013). Clearly, additional measures are required for a timely, technically and economically feasible transition to a low carbon energy system. One such measure would be capture and geological storage of $\mathrm{CO}_{2}$ (CCS). CCS could be effectively applied to coal and gas fuelled power plants, as well as to fossil fuel consuming industries. Whereas it has been proposed since the late 1980s, 
the implementation of CCS has been hampered mainly by political and economical challenges (Metz et al., 2005; Birol, 2013). Clearly, the economical prospects of CCS would benefit greatly from a reduction in the cost of capture, being the most expensive part of the CCS chain, and/or an increase in the price of $\mathrm{CO}_{2}$ emission allowances.

One process scheme with a high potential of bringing down the cost of $\mathrm{CO}_{2}$ capture is integrated precombustion $\mathrm{CO}_{2}$ capture and hydrogen production by sorption-enhanced water-gas shift (SEWGS). SEWGS combines the water-gas shift (WGS) reaction (1) with in situ adsorption of $\mathrm{CO}_{2}(2)$, at about $300-500{ }^{\circ} \mathrm{C}$ and 10-40 bar.

$\mathrm{CO}+\mathrm{H}_{2} \mathrm{O} \rightleftharpoons \mathrm{CO}_{2}+\mathrm{H}_{2} \quad \Delta H^{\circ} 298 \mathrm{~K}=-41 \mathrm{~kJ} \mathrm{~mol}^{-1}$

$\mathrm{CO}_{2}+\bullet \rightleftharpoons \mathrm{CO}_{2}-\bullet$

$\mathrm{H}_{2} \mathrm{O}+\bullet \rightleftharpoons \mathrm{H}_{2} \mathrm{O}-\bullet$

A potassium promoted hydrotalcite (K-HTC) catalyses the WGS reaction (1) and is capable of reversibly adsorbing $\mathrm{CO}_{2}$ (Hufton et al., 1999; Yong et al., 2002; Lee et al., 2008; Boon et al., 2014). Relatively pure $\mathrm{CO}_{2}$ is released during regeneration of the K-HTC. Because of the periodic loading and regeneration of the sorbent, a state of the art SEWGS process comprises multiple columns which are operated in pressure cycles, resembling the cycles of a pressure swing adsorption (PSA) process and allowing the production of continuous product streams (see Fig. 1). After the adsorption step, a $\mathrm{CO}_{2}$ or $\mathrm{H}_{2} \mathrm{O}$ rinse is performed to improve the $\mathrm{CO}_{2}$ product purity, by preventing the loss of efficiency due to the slip of $\mathrm{H}_{2}$ into the $\mathrm{CO}_{2}$ product. Depressurisation is followed by a steam purge to allow a high recovery of $\mathrm{CO}_{2}$ and to enhance sorbent regeneration. The detailed discussion of all steps in the SEWGS cycle continues below. Thus, the overall process directly converts syngas into separate streams of $\mathrm{H}_{2}$ at $10-40$ bar and $\mathrm{CO}_{2}$ at lower pressure, both at $400{ }^{\circ} \mathrm{C}$. The SEWGS process is therefore exceptionally suited for precombustion $\mathrm{CO}_{2}$ capture, and hence mitigation of greenhouse gas emissions. In fact, Manzolini et al. (2013a) have recently shown that for a coal fuelled IGCC power plant, the cost of $\mathrm{CO}_{2}$ avoided can be brought down with SEWGS by $15 \%$ or more, compared to state of the art precombustion $\mathrm{CO}_{2}$ capture by Selexol, to $31-33 € \mathrm{t}_{\mathrm{CO}_{2}}^{-1}$ (K-HTC sorbent alpha: $-15 \%$ ) or even $23-25 € \mathrm{t}_{\mathrm{CO}_{2}}^{-1}$ (K-HTC next generation sorbent beta, -35\%). Excluding $\mathrm{CO}_{2}$ compression, the costs of $\mathrm{CO}_{2}$ capture with SEWGS were shown to come mainly from investment costs $(55 \%$ of the increased cost of electricity) and additional fuel costs for production of high-pressure rinse steam and low-pressure purge steam (23\% of the increased cost of electricity)-the economy of the SEWGS process is dominated by investment cost and steam consumption.
Although the concept of SEWGS is not new (Chemische Fabrik Griesheim-Elektron, 1915; Gülker, 1927; Gluud et al., 1931), a major breakthrough in efficiency since the early twentieth century came with the development of K-HTC sorbent, a sorbent (Hufton et al. 1999) that can be efficiently regenerated by pressure swing. Since then, considerable progress has been made in the materials science behind the sorbent, in understanding the sorbent-sorbate interaction, and in the development of SEWGS cycles-all in all SEWGS is now classified on NASA's technology readiness level 5-6 (Jansen et al., 2013). Firstly, in sorbent preparation, it has been shown that the Mg:Al ratio of the sorbent plays a crucial part (Oliveira et al., 2008). Depending on this ratio and operating conditions, bulk $\mathrm{MgCO}_{3}$ can be formed during adsorption, which leads to very high capacities (Walspurger et al., 2010; Marono et al., 2013), yet at the same time gives rise to $\mathrm{CO}_{2}$ slip and loss of mechanical integrity in a SEWGS cycle (van Selow et al., 2009b). Secondly, sorbent-sorbate interaction has been the subject of many studies, indicating that different sites and mechanisms on the sorbent may play a role in the adsorption of $\mathrm{CO}_{2}(2)$ and $\mathrm{H}_{2} \mathrm{O}$ (3) at the relevant temperature and partial pressure levels (Lee et al., 2007; Ebner et al., 2007; Oliveira et al., 2008; Walspurger et al., 2010, 2011; Wang et al., 2012; vanSelow et al., 2013; Wu et al., 2013; Marono et al., 2013; Marono et al., 2014; Boon et al., 2014). Thirdly, SEWGS cycles have received less attention so far. Allam et al. (2005) have developed a SEWGS cycle in which the adsorption step is followed by a high pressure rinse with repressurised $\mathrm{CO}_{2}$ product, in order to remove syngas species present in the column voids and enhance the $\mathrm{CO}_{2}$ product purity. In modelling studies by Wright et al. (2009) and van Selow et al. (2009a), the use of rinse steam instead of $\mathrm{CO}_{2}$ was shown to significantly improve the efficiency of the cycle. Reijers et al. (2011) have simulated a steam rinse cycle and shown the importance of rinse for the $\mathrm{CO}_{2}$ product purity and the $\mathrm{CO}_{2}$ recovery to increase with increasing purge. For $90 \%$ carbon capture ratio and $98 \% \mathrm{CO}_{2}$ purity, they found an optimum $S / C_{\text {rinse }}$ of 0.55 and $S / C_{\text {purge }}$ of 1.3 . For sorbent alpha, Gazzani et al. (2013) used a $S / C_{\text {rinse }}$ of 0.44 and a $\mathrm{S} / \mathrm{C}_{\text {purge }}$ of 1.06 in order to obtain $95 \%$ carbon capture ratio and $99 \%$ $\mathrm{CO}_{2}$ purity. Wright et al. (2011) have shown that a significant improvement can be made to decrease steam consumption by increasing the number of pressure equalisation steps from one to three, although this must be balanced with higher investment costs because of the larger number of columns. They arrived at a total $\mathrm{S} / \mathrm{C}$ of 1.9 for precombustion $\mathrm{CO}_{2}$ capture in an IGCC. Jansen et al. (2013) have shown the impact of purge steam on the carbon capture ratio, and of both $\mathrm{S} / \mathrm{C}_{\text {rinse }}$ and $\mathrm{S} / \mathrm{C}_{\text {purge }}$ on the $\mathrm{CO}_{2}$ purity.

The state of the art SEWGS cycle follows a number of steps that govern the performance of the process. The steps are schematically shown in Fig. 1 for the SEWGS cycle proposed in the current work, aiming at a high carbon capture ratio and $\mathrm{CO}_{2}$ purity for a power plant configuration. First, during the adsorption step,

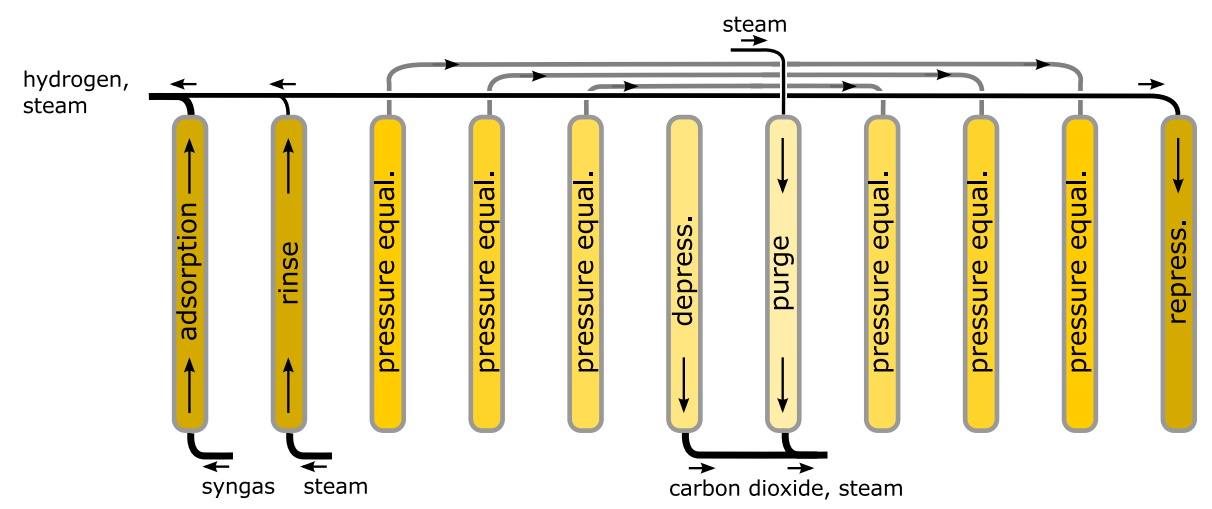

Fig. 1. 11-step SEWGS cycle with co-current steam rinse. 
syngas is converted at high pressure through WGS (1), while $\mathrm{CO}_{2}$ is adsorbed (2). Then, a high pressure rinse is performed, in which part of the unconverted syngas in the column is replaced by $\mathrm{H}_{2} \mathrm{O}$. The use of rinse originates from PSA cycle design (Yang, 1987) and is known to improve the $\mathrm{CO}_{2}$ purity. During the rinse, additional $\mathrm{H}_{2}$ product is produced. After the rinse step, a number of pressure equalisation steps are carried out, in which a high pressure column is connected to a lower pressure column, in order to exchange gas from columns at higher pressure to columns in a lower pressure part of the cycle. This serves to reduce the amount of gas fed to the column for repressurisation. Additionally, the rinse gas is expanded causing syngas, that would otherwise become impurities in the $\mathrm{CO}_{2}$ product, to be transported to another column that can use it in the upcoming adsorption step. During the depressurisation step, relatively pure $\mathrm{CO}_{2}$ product is collected. In order to further desorb $\mathrm{CO}_{2}$, a low pressure purge step follows. Once sufficient $\mathrm{CO}_{2}$ has been recovered, the column is repressurised, first by pressure equalisation and finally by repressurisation with $\mathrm{H}_{2}$ product, or alternatively with syngas. For the overall SEWGS cycle, the design criteria are generally formulated in terms of the carbon capture ratio, the amount of $\mathrm{CO}_{2}$ product recovered divided by the amount of $\mathrm{CO}$ and $\mathrm{CO}_{2}$ fed, and the $\mathrm{CO}_{2}$ purity. The former quantifies the amount of carbon that can be captured from the feed. The latter is important mainly because any $\mathrm{H}_{2}$ and $\mathrm{CO}$ that end up in the $\mathrm{CO}_{2}$ product will reduce the efficiency of the process. The performance of the cycle within these design criteria can be expressed in three dependent variables: (1) productivity, the amount of $\mathrm{CO}_{2}$ produced per unit time per amount of sorbent, (2) rinse steam consumption $\left(S / C_{\text {rinse }}\right)$, the amount of steam used in the rinse relative to the amount of $\mathrm{CO}$ and $\mathrm{CO}_{2}$ fed, and (3) purge steam consumption $\left(S / C_{\text {purge }}\right)$, the amount of steam used in the purge relative to the amount of $\mathrm{CO}$ and $\mathrm{CO}_{2}$ fed. The optimal SEWGS cycle would consequently minimise cost (CAPEX) and energy penalty (OPEX), by optimisation of the total steam consumption and productivity.

The development of a SEWGS cycle requires a prolonged endeavour, based on the three fields designated above. In terms of sorbent, the cause and conditions of detrimental $\mathrm{MgCO}_{3}$ formation (van Selow et al., 2009b; Walspurger et al., 2010, 2011) has been studied, and a stable successor was developed (sorbent alpha, Gazzani et al., 2013). It has been shown that the K-HTC sorbent is sufficiently catalytically active for the WGS reaction, so an additional catalyst can be omitted (van Dijk et al., 2011; vanSelow et al., 2013), and that the $\mathrm{CO}_{2}$-sorbent interaction is not affected by $\mathrm{H}_{2} \mathrm{~S}$ and other impurities (van Dijk et al., 2011; Jansen et al., 2013). In terms of understanding the sorption equilibrium, the role of potassium sites has been elucidated (Walspurger et al., 2008). Recently, a new adsorption isotherm has been presented that encompasses the SEWGS partial pressure range for $\mathrm{CO}_{2}$ and $\mathrm{H}_{2} \mathrm{O}$ on $\mathrm{K}-\mathrm{HTC}$, based on preferential surface adsorption and competitive nanopore adsorption (Boon et al., 2014). In terms of cycle design, the improved performance of the $\mathrm{H}_{2} \mathrm{O}$ rinse, when compared to the $\mathrm{CO}_{2}$ rinse has been addressed (van Selow et al., 2009a), and the importance of several operating parameters has been assessed (Reijers et al., 2011). A logical next step in SEWGS development is an evaluation of the cycle performance with the improved adsorption isotherm.

The current work aims to evaluate the performance of the SEWGS cycle with the newly developed isotherm, i.e. including both surface adsorption and competitive nanopore adsorption for $\mathrm{CO}_{2}$ and $\mathrm{H}_{2} \mathrm{O}$. A state of the art SEWGS cycle is used, with 9 columns, co-current rinse, and three pressure equalisations. Simulation results will be discussed in terms of the effect of operating conditions (cycle time, rinse steam flow rate, and purge steam flow rate) on the cycle performance (carbon capture ratio and $\mathrm{CO}_{2}$ purity). Based on these data, improved operating conditions in terms of productivity and steam consumption are identified. Finally, the impact of competitive adsorption of $\mathrm{CO}_{2}$ and $\mathrm{H}_{2} \mathrm{O}$ on the performance of the SEWGS cycle is discussed.

\section{Methods}

A reactor model for a single SEWGS column, based on a binary adsorption isotherm and linear driving force mass transfer kinetics has recently been published by Boon et al. (2014). Additional relevant aspects, as well as implementation of the SEWGS cycle model are discussed below.

\subsection{SEWGS isotherm and column model}

Boon et al. (2014) derived a new isotherm for the adsorption of $\mathrm{CO}_{2}$ and $\mathrm{H}_{2} \mathrm{O}$ on K-HTC. The isotherm is based on additive contributions of surface and nanopores for the adsorption of $\mathrm{CO}_{2}$ and $\mathrm{H}_{2} \mathrm{O}$. Surface sites are specific in the sense that they adsorb either $\mathrm{CO}_{2}$ or $\mathrm{H}_{2} \mathrm{O}$, as described by Langmuir and Freundlich isotherms, respectively. Competitive adsorption occurs in the nanopores, which is described using a Dubinin-Astakhov equation based on volume filling theory. The isotherm (Eqs. (4)-(6)) is plotted in Fig. 2. Throughout the partial pressure range, the adsorption of $\mathrm{CO}_{2}$ is only slightly affected by the steam partial pressure. Steam adsorption, on the other hand, does significantly depend upon the $\mathrm{CO}_{2}$ partial pressure, particularly for steam partial pressures over 10 bar.

$$
\begin{aligned}
& q_{\mathrm{CO}_{2}}^{\mathrm{eq}}=\frac{q_{\mathrm{CO}_{2}}^{\mathrm{s}} K_{\mathrm{CO}_{2}} p_{\mathrm{CO}_{2}}}{1+K_{\mathrm{CO}_{2}} p_{\mathrm{CO}_{2}}}+\frac{A_{\mathrm{CO}_{2}}\left(V_{0}-V_{0} A_{\mathrm{H}_{2} \mathrm{O}}\right)}{v_{\mathrm{m}, \mathrm{CO}_{2}}\left(1-A_{\mathrm{CO}_{2}} A_{\mathrm{H}_{2} \mathrm{O}}\right)} \\
& q_{\mathrm{H}_{2} \mathrm{O}}^{\mathrm{eq}}=K_{\mathrm{H}_{2} \mathrm{O}} p_{\mathrm{H}_{2} \mathrm{O}}^{1 / n}+\frac{A_{\mathrm{H}_{2} \mathrm{O}}\left(V_{0}-V_{0} A_{\mathrm{CO}_{2}}\right)}{v_{\mathrm{m}, \mathrm{H}_{2} \mathrm{O}}\left(1-A_{\mathrm{CO}_{2}} A_{\mathrm{H}_{2} \mathrm{O}}\right)} \\
& A_{i}=\exp \left(-\left[\left(\frac{R T}{E_{i}}\right) \ln \left(\frac{p_{0, i}}{p_{i}}\right)\right]^{m_{i}}\right)
\end{aligned}
$$

Column model equations are summarised in Tables 1 and 2 . The intraparticle mass transfer resistance is described by a linear driving force, as discussed by Boon et al. (2014) and constitutive equations have been taken from the literature (Bird et al., 1960; Ruthven, 1984; Westerterp et al., 1987; Yang, 1987; Poling et al., 2001). Model parameters specific for the SEWGS process are summarised in Table 3. The geometry of the SEWGS columns was not varied; the column dimensions used by Gazzani et al. (2013) were taken as representative of industrial size SEWGS columns. Model validation and numerical solution strategy were discussed before (Boon et al., 2014).

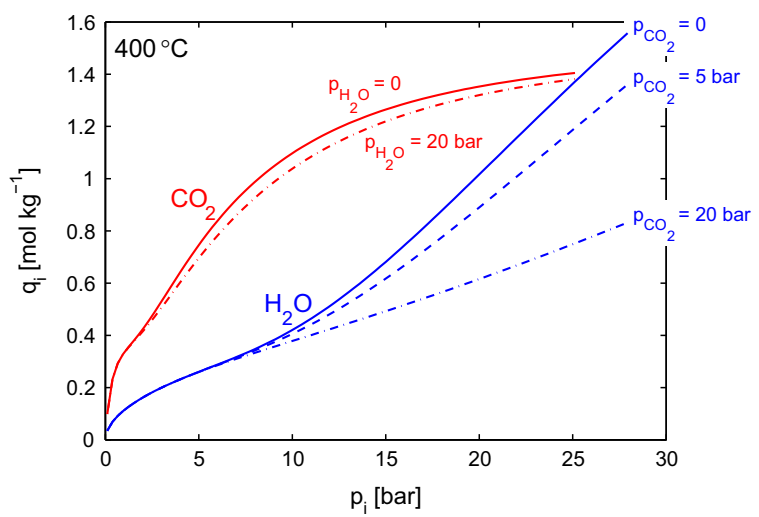

Fig. 2. Adsorption isotherm for $\mathrm{CO}_{2}$ (red) and $\mathrm{H}_{2} \mathrm{O}$ (blue) (Boon et al., 2014). (For interpretation of the references to color in this figure caption, the reader is referred to the web version of this article.) 
Table 1

Column model equations.

\begin{tabular}{llc}
\hline Continuity & $\frac{\partial \rho}{\partial t}=-\frac{\partial \rho v}{\partial z}+\frac{1-\epsilon_{\mathrm{b}}}{\epsilon_{\mathrm{b}}} a_{\mathrm{p}} \sum_{i} M_{i} N_{i}$ & A \\
Momentum & $0-\frac{\partial p}{\partial z}-f \frac{\rho|u| u}{d_{\mathrm{p}}}$ & B \\
Heat balance & $\left(\epsilon_{\mathrm{b}} \rho C_{\mathrm{p}}+\left(1-\epsilon_{\mathrm{b}}\right) \rho_{\mathrm{p}} C_{p, \mathrm{p}}\right) \frac{\partial T}{\partial t}$ & $\mathrm{C}$ \\
$=-\rho C_{\mathrm{p}} u \frac{\partial T}{\partial z}+\frac{\partial}{\partial z}\left(\lambda \frac{\partial T}{\partial z}\right)+\frac{4 U\left(T_{\mathrm{w}}-T\right)}{d_{\mathrm{c}}}$ & \\
& $-\left(1-\epsilon_{\mathrm{b}}\right) \rho_{\mathrm{p}}\left(\left(-\Delta H_{\mathrm{r}}\right) r_{\mathrm{WGS}}+\sum_{i}\left(-\Delta H_{\mathrm{a}, i} \frac{d\left\langle q_{i}\right\rangle}{d t}\right)\right)$ & $\mathrm{D}$ \\
Mass balance & $\frac{\partial\left(\rho \omega_{i}\right)}{\partial t}=-\frac{\partial \rho v \omega_{i}}{\partial z}+\frac{\partial}{\partial z}\left(D_{z} \rho \frac{\partial \omega_{i}}{\partial z}\right)+\frac{1-\epsilon_{\mathrm{b}}}{\epsilon_{\mathrm{b}}} a_{\mathrm{p}} M_{i} N_{i}$ & \\
\hline
\end{tabular}

Table 2

Intraparticle equations.

\begin{tabular}{llc}
\hline $\begin{array}{l}\text { Intraparticle } \\
\text { mass balance }\end{array}$ & $\frac{d\left\langle c_{i}\right\rangle}{d t}=k_{\mathrm{LDF}, i}\left(c_{\mathrm{int}, i}-\left\langle c_{i}\right\rangle\right)$ & $\mathrm{E}$ \\
$\begin{array}{l}\mathrm{LDF} \text { mass transfer } \\
\text { coefficient }\end{array}$ & $k_{\mathrm{LDF}, i}=\frac{15 \mathcal{D}_{\mathrm{p}, i}}{r_{\mathrm{p}}^{2}\left(\epsilon_{\mathrm{p}}+\rho_{\mathrm{p}} \frac{\partial q_{i}}{\partial c_{i}}\right)}$ & $\mathrm{F}$ \\
$\begin{array}{l}\text { Multicomponent } \\
\text { isotherm }\end{array}$ & $\left\langle q_{i}\right\rangle=f\left(\left\langle c_{1 \ldots N}\right\rangle\right)$ & $\mathrm{G}$ \\
\hline
\end{tabular}

Table 3

SEWGS process parameters.

\begin{tabular}{ll}
\hline $\mathrm{L}$ & $12.2 \mathrm{~m}$ \\
$d_{\mathrm{c}}$ & $3.66 \mathrm{~m}$ \\
$T_{\text {wall }}$ & $400{ }^{\circ} \mathrm{C}$ \\
$\rho_{\mathrm{p}}$ & $1329 \mathrm{~kg} \mathrm{~m}^{-3}$ \\
$\epsilon_{\mathrm{b}}$ & 0.38 \\
$\epsilon_{\mathrm{p}}$ & 0.65 \\
$d_{\mathrm{p}}$ & $4.75 \mathrm{~mm}$ \\
$q_{\mathrm{CO}_{2}}^{\mathrm{s}}$ & $0.45 \mathrm{~mol} \mathrm{~kg}^{-1}$ \\
$K_{\mathrm{CO}_{2}}(673 \mathrm{~K})$ & $28 \mathrm{MPa}^{-1}$ \\
$E_{\mathrm{CO}_{2}}$ & $23 \mathrm{~kJ} \mathrm{~mol}^{-1}$ \\
$m_{\mathrm{CO}_{2}}$ & 5.2 \\
$K_{\mathrm{H}_{2} \mathrm{O}}(673 \mathrm{~K})$ & $0.37 \mathrm{~mol} \mathrm{~kg}^{-1} \mathrm{MPa}^{-1 / 1.9}$ \\
$n$ & 1.9 \\
$E_{\mathrm{H}_{2} \mathrm{O}}$ & $12 \mathrm{~kJ} \mathrm{~mol}^{-1}$ \\
$m_{\mathrm{H}_{2} \mathrm{O}}$ & 3.6 \\
$V_{0}$ & $74 \mathrm{~cm}^{3} \mathrm{~kg}^{-1}$ \\
$C_{p, \mathrm{p}}$ & $1048 \mathrm{~J} \mathrm{~kg}^{-1} \mathrm{~K}^{-1}$ \\
$\Delta H_{\mathrm{a}, \mathrm{CO}}$ & $-65 \mathrm{~kJ} \mathrm{~mol}^{-1}$ \\
$\Delta H_{\mathrm{a}, \mathrm{H}_{2} \mathrm{O}}$ & $-50 \mathrm{~kJ} \mathrm{~mol}^{-1}$ \\
\hline
\end{tabular}

\subsection{Pressure swing SEWGS cycle}

The single column model was extended to simulate consecutively all steps of a complete SEWGS cycle for $\mathrm{CO}_{2}$ capture in an IGCC power plant. The SEWGS cycle consisted of 11 steps:

1. adsorption,

2. co-current steam rinse,

3. pressure equalisation 1 (providing step),

4. pressure equalisation 2 (providing step),

5. pressure equalisation 3 (providing step),

6. depressurisation,

7. purge,

8. pressure equalisation 3 (receiving step),

9. pressure equalisation 2 (receiving step),

10. pressure equalisation 1 (receiving step),

11. repressurisation.

Cycle timing for 9 columns in parallel is depicted in Fig. 3, showing two columns concurrently in adsorption mode and timing of the pressure equalisation steps. Similar cycles with co-current $\mathrm{CO}_{2}$ rinse and counter-current $\mathrm{H}_{2} \mathrm{O}$ rinse were proposed by van Selow et al. (2009a). Boundary conditions are shown in Table 4. Power plant model data presented by Gazzani et al. (2013) were used for the feed conditions.

$\mathrm{H}_{2} \mathrm{~S}$ and other impurities that can be present in the feed as well as in the rinse and purge steam are not accounted for explicitly. $\mathrm{H}_{2} \mathrm{~S}$ adsorbs on basic metal oxides such as K-HTC. Toops and Crocker (2008) have elucidated different mechanisms to contribute to the capacity of HTC for $\mathrm{H}_{2} \mathrm{~S}$ adsorption at room temperature, including dissociative surface adsorption and incorporation of $\mathrm{S}^{2-}$ in the metal oxide matrix. A similar mechanism to the latter was observed for the adsorption of COS, among the formation of other, more complex sulphur species. Van Dijk et al. (2011) have shown in lab scale tests at $400{ }^{\circ} \mathrm{C}$ that K-HTC captures $\mathrm{CO}_{2}$ and $\mathrm{H}_{2} \mathrm{~S}$ simultaneously, proposing two types of sites. On one type, either $\mathrm{CO}_{2}$ or $\mathrm{H}_{2} \mathrm{~S}$ can adsorb, on the other only $\mathrm{H}_{2} \mathrm{~S}$ can adsorb, potentially involving the formation of metal sulphides. The net effect for a SEWGS cycle is that $\mathrm{H}_{2} \mathrm{~S}$ will end up in the $\mathrm{CO}_{2}$ product. Indeed, van Selow et al. (2013) have demonstrated the combined capture of $\mathrm{H}_{2} \mathrm{~S}$ and $\mathrm{CO}_{2}$ from syngas in bench scale tests. Finally, experiments with various impurities under SEWGS conditions have shown that COS is hydrolysed and adsorbed as $\mathrm{H}_{2} \mathrm{~S}, \mathrm{CH}_{4}$ is neither converted nor adsorbed and will therefore end up in the $\mathrm{H}_{2}$ product stream, and $\mathrm{NH}_{3}$ and $\mathrm{HCN}$ are partially captured (Jansen et al., 2013). In conclusion, neither of these impurities will upset the SEWGS cycle, which will produce a $\mathrm{H}_{2}$ product stream with low contents of $\mathrm{CO}_{2}, \mathrm{COS}$ and $\mathrm{H}_{2} \mathrm{~S}$ and a $\mathrm{CO}_{2}$ product stream with $\mathrm{H}_{2} \mathrm{~S}$.

Numerically, a single column is simulated in time while connecting steps are temporarily stored in a spreadsheet file. Timing is controlled by setting the total cycle time and division over the steps as indicated by the relative duration in Table 4 . The simulation continues for a number of cycles until cyclic steady state is reached. Depending on the initial state of the column, 20-30 cycles are typically required for the amount of $\mathrm{CO}_{2}$ in the column and the pressure levels of the equalisation steps to converge and for the SEWGS process to reach cyclic steady state. In order to save time, the column is divided relatively coarsely into 200 finite differences, but it was verified that a more refined grid of 400 points yielded the same results.

After the adsorption step, a co-current $\mathrm{H}_{2} \mathrm{O}$ rinse displaces part of the unconverted syngas near the column inlet and produces additional $\mathrm{H}_{2}$ product (Fig. 1). Then, three subsequent top to top pressure equalisation steps are performed, in which the high pressure columns are connected to the low pressure columns. After the pressure equalisation steps, the $\mathrm{CO}_{2}$ product is recovered in the depressurisation and purge steps. During the purge, steam is fed to the column to lower the $\mathrm{CO}_{2}$ partial pressure and enhance sorbent regeneration. Then, the pressure in the column is increased in steps. First, in three pressure equalisations, the column is fed from the providing high pressure columns. The final pressures of the columns in these steps are the result of the simulation and depend on the initial pressure, feed conditions, and mass exchange with the sorbent. Finally, the repressurisation step is done by taking part of the $\mathrm{H}_{2}$ product.

The simulation is run with the standard parameters detailed above (Tables 3 and 4). As explained in the introduction, the performance indicators of the SEWGS process are formulated in terms of carbon capture ratio and $\mathrm{CO}_{2}$ purity. After identifying a case near the optimum, additional simulations were performed to test the behaviour of the SEWGS process as a function of the adsorption isotherm. Firstly, a simulation was performed without adsorption of steam $\left(q_{\mathrm{H}_{2} \mathrm{O}}=0\right)$. Then, a series of simulations was performed in order to study the effect of the linear driving force intraparticle mass transfer coefficient on the performance of the SEWGS cycle. 


\begin{tabular}{|c|c|c|c|c|c|c|c|c|c|c|c|c|c|c|c|c|c|c|}
\hline \multirow{3}{*}{$\begin{array}{l}\text { Column } 1 \\
\text { Column } 2 \\
\text { Column } 3\end{array}$} & \multicolumn{4}{|c|}{ adsorption } & \multicolumn{2}{|c|}{ rinse } & \multirow{2}{*}{\multicolumn{2}{|c|}{\begin{tabular}{|c|c|} 
peq1 & peq2 \\
rinse \\
\end{tabular}}} & \multirow{2}{*}{\begin{tabular}{|l|} 
peq3 \\
peq1 \\
\end{tabular}} & \multirow{2}{*}{\begin{tabular}{c|} 
dep \\
peq2
\end{tabular}} & \multicolumn{4}{|c|}{ purge } & peq3 & peq2 & \multirow{2}{*}{$\frac{\text { peq1 }}{\text { peq3 }}$} & \multirow{2}{*}{$\begin{array}{l}\text { rep } \\
\text { peq2 }\end{array}$} \\
\hline & \multirow{2}{*}{\begin{tabular}{|l|} 
peq1 \\
peq3
\end{tabular}} & \multirow{2}{*}{$\begin{array}{c}\text { rep } \\
\text { peq2 }\end{array}$} & \multicolumn{4}{|c|}{ adsorption } & & & & & peq3 & dep & \multicolumn{4}{|c|}{ purge } & & \\
\hline & & & peq1 & rep & \multicolumn{4}{|c|}{ adsorption } & \multirow{2}{*}{\multicolumn{2}{|c|}{ ption }} & peq1 & peq2 & peq3 & & \multicolumn{4}{|c|}{ purge } \\
\hline Column 4 & \multicolumn{2}{|c|}{ purge } & peq3 & peq2 & peq1 & rep & \multicolumn{2}{|c|}{ adsorption } & & & \multicolumn{2}{|c|}{ rinse } & peq1 & peq2 & peq3 & dep & \multicolumn{2}{|c|}{ purge } \\
\hline Column 5 & \multicolumn{4}{|c|}{ purge } & peq3 & peq2 & peq1 & rep & \multicolumn{4}{|c|}{ adsorption } & \multicolumn{2}{|c|}{ rinse } & peq1 & peq2 & peq3 & dep \\
\hline Column 6 & peq3 & dep & \multicolumn{4}{|c|}{ purge } & peq3 & peq2 & peq1 & rep & \multicolumn{4}{|c|}{ adsorption } & \multicolumn{2}{|c|}{ rinse } & peq1 & peq2 \\
\hline Column 7 & peq1 & peq2 & peq3 & dep & \multicolumn{4}{|c|}{ purge } & peq3 & peq2 & peq1 & rep & \multicolumn{4}{|c|}{ adsorption } & \multicolumn{2}{|c|}{ rinse } \\
\hline Column 8 & \multicolumn{2}{|c|}{ rinse } & peq1 & peq2 & peq3 & dep & \multicolumn{4}{|c|}{ purge } & peq3 & peq2 & peq1 & rep & \multicolumn{4}{|c|}{ adsorption } \\
\hline Column 9 & \multicolumn{2}{|c|}{ adsorption } & & & peq1 & peq2 & peq3 & dep & & pur & ge & & peq3 & peq2 & peq1 & rep & adsor & ption \\
\hline $\begin{array}{l}\text { Relative } \\
\text { duration }\end{array}$ & $1 / 18$ & $1 / 18$ & $1 / 18$ & $1 / 18$ & $1 / 18$ & $1 / 18$ & $1 / 18$ & $1 / 18$ & $1 / 18$ & $1 / 18$ & $1 / 18$ & $1 / 18$ & $1 / 18$ & $1 / 18$ & $1 / 18$ & $1 / 18$ & $1 / 18$ & $1 / 18$ \\
\hline
\end{tabular}

Fig. 3. 9 columns for 11-step SEWGS cycle with co-current $\mathrm{H}_{2} \mathrm{O}$ rinse and counter-current $\mathrm{H}_{2} \mathrm{O}$ purge.

Table 4

SEWGS cycle boundary conditions for a single train of 9 columns.

\begin{tabular}{|c|c|}
\hline \multicolumn{2}{|l|}{ Feed } \\
\hline Relative duration & $4 / 18$ \\
\hline$F_{\mathrm{m}}$ & $15.05 \mathrm{~kg} \mathrm{~s}^{-1}$ \\
\hline$p_{\text {out }}$ & 24 bar \\
\hline$\omega_{\mathrm{Ar}}$ & 0.008 \\
\hline$\omega_{\mathrm{H}_{2} \mathrm{O}}$ & 0.276 \\
\hline$\omega_{\mathrm{H}_{2}}$ & 0.036 \\
\hline$\omega_{\mathrm{CO}}$ & 0.071 \\
\hline$\omega_{\mathrm{CO}_{2}}$ & 0.544 \\
\hline$\omega_{\mathrm{N}_{2}}$ & 0.065 \\
\hline \multicolumn{2}{|l|}{ Rinse } \\
\hline Relative duration & $2 / 18$ \\
\hline$F_{\mathrm{m}}$ & Varied \\
\hline$p_{\text {out }}$ & 24 bar \\
\hline$\omega_{\mathrm{H}_{2} \mathrm{O}}$ & 1 \\
\hline \multicolumn{2}{|c|}{ Pressure equalisation $1-3$} \\
\hline Relative duration & $1 / 18$ \\
\hline$p_{\text {out }}$ & Interpolated \\
\hline \multicolumn{2}{|l|}{ Depressurisation } \\
\hline Relative duration & $1 / 18$ \\
\hline$p_{\text {out }}$ & Interpolated \\
\hline \multicolumn{2}{|l|}{ Purge } \\
\hline Relative duration & $4 / 18$ \\
\hline$F_{\mathrm{m}}$ & Varied \\
\hline$p_{\text {out }}$ & 1.1 bar \\
\hline$\omega_{\mathrm{H}_{2} \mathrm{O}}$ & 1 \\
\hline \multicolumn{2}{|c|}{ Pressure equalisation 3-1 } \\
\hline Relative duration & $1 / 18$ \\
\hline$F_{\mathrm{m}}$ & From providing steps \\
\hline \multicolumn{2}{|l|}{ Repressurisation } \\
\hline Relative duration & $1 / 18$ \\
\hline$F_{\mathrm{m}}$ & interpolated \\
\hline
\end{tabular}

\subsection{Parameter study}

A parameter study was done in order to evaluate the performance of the SEWGS cycle under different operating conditions. Aiming at $95 \%$ carbon capture ratio and $99 \% \mathrm{CO}_{2}$ purity, the performance data from EU FP7 Caesar project reported by Gazzani et al. (2013) is used as a starting point: $S / C_{\text {rinse }}=0.44$, and $S / C_{\text {purge }}=1.06$ ('Case 0 '). Around the starting point, simulations are run for cycle times in the range of 200-750 s, $S / C_{\text {rinse }}$ $0.001-0.5$, and $S / C_{\text {purge }} 0.001-2$. When changing the total cycle time, the relative duration of each step and the feed flow rate are not changed. Each of the conditions yields a cyclic steady state with carbon capture ratio and $\mathrm{CO}_{2}$ purity values. The performance data are then interpolated in order to find solutions that match the criteria of $95 \%$ carbon capture ratio and $99 \% \mathrm{CO}_{2}$ purity. Rather than a rigorous optimisation in a mathematical sense, this is a heuristic parametric analysis of the SEWGS cycle.

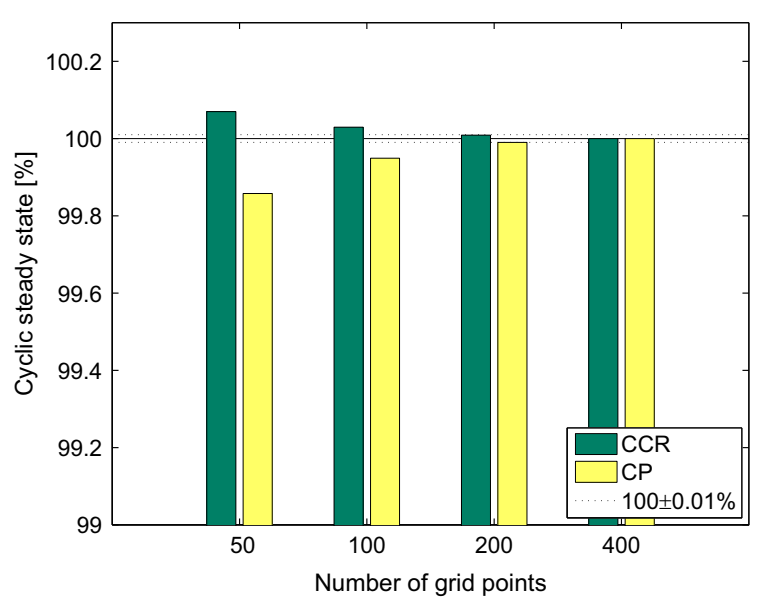

Fig. 4. Cyclic steady state simulation result as a function of grid size, relative to result with 400 grid points (Case 1; 400 grid points yields carbon capture ratio $0.9666, \mathrm{CO}_{2}$ purity 0.9960$)$.

\section{Results and discussion}

\subsection{Pressure swing SEWGS cycle}

Out of the simulation conditions, the simulation with cycle time $700 \mathrm{~s}, \mathrm{~S} / \mathrm{C}_{\text {rinse }} 0.06$, and $\mathrm{S} / \mathrm{C}_{\text {purge }} 0.1$ ('Case 1') using 200 grid points was repeated with 50,100 , and 400 grid points. As shown in Fig. 4 , the obtained $\mathrm{CO}_{2}$ purity in cyclic steady state was sensitive to the used number of grid points, which appears to be related to the role of relatively sharp concentration profiles in the rinse and subsequent depressurisation steps (see the discussion on rinse below). Between 200 and 400 grid points, no significant difference $(<0.01 \%)$ exists and the former was chosen to perform the cycle simulations presented here.

\subsubsection{SEWGS cycle steps}

The evolution of the $\mathrm{CO}_{2}$ mole fraction and $\mathrm{CO}_{2}$ and $\mathrm{H}_{2} \mathrm{O}$ solid loading during the Case 1 SEWGS cycle in cyclic steady state is detailed in Fig. 5, the pressure profile is shown in Fig. 6. During adsorption, as syngas is fed, the $\mathrm{CO}_{2}$ profile advances through the column while $\mathrm{CO}_{2}$ adsorbs. Before large amounts of the $\mathrm{CO}_{2}$ can reach the column outlet, in order to prevent a deterioration in carbon capture ratio, the adsorption is stopped and a co-current $\mathrm{H}_{2} \mathrm{O}$ rinse is performed. The $\mathrm{H}_{2} \mathrm{O}$ strongly adsorbs, yet some of the $\mathrm{CO}_{2}$ in the column is already displaced. The well known roll-up (roll-over) effect, in which a weaker adsorbate is displaced by a stronger adsorbate (Yang, 1987), is witnessed by the increase in $\mathrm{CO}_{2}$ concentration just before the $\mathrm{H}_{2} \mathrm{O}$ front. The roll-up effect is rather subtle, which is due to the relatively modest impact of steam upon the amount of $\mathrm{CO}_{2}$ adsorbed (see Fig. 2) when 
a

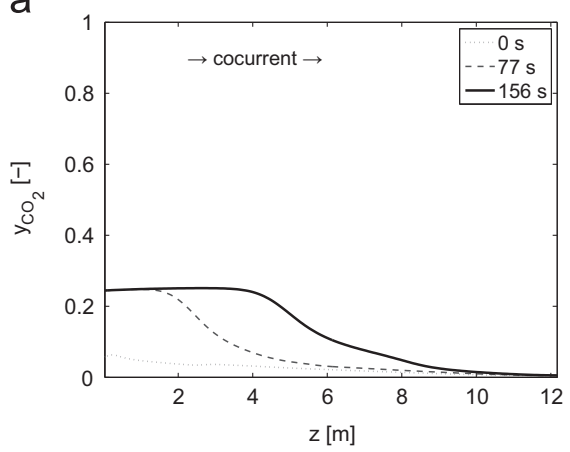

d

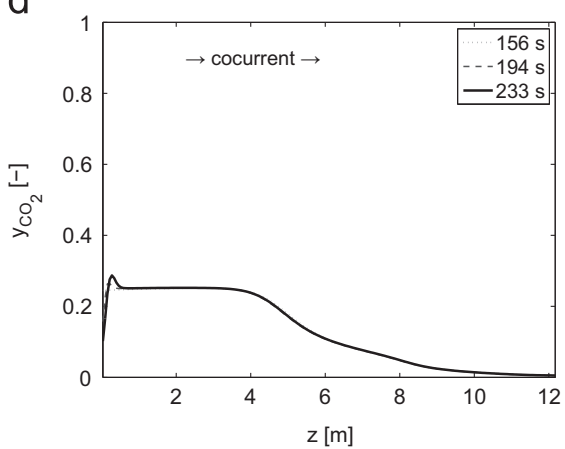

g

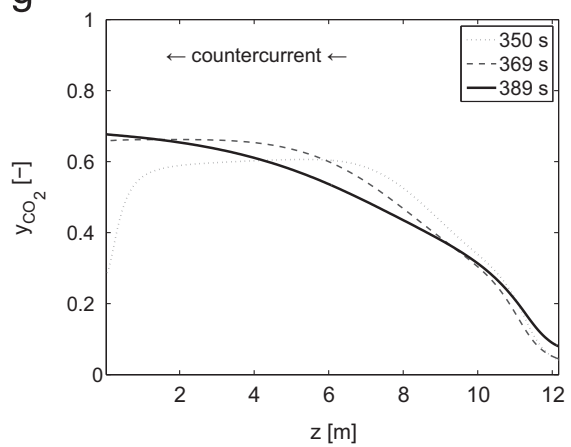

j

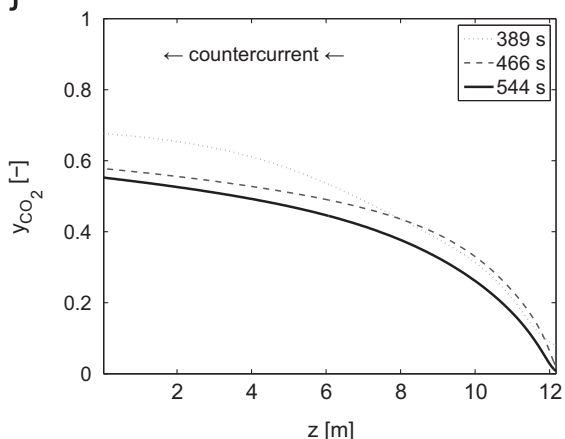

b

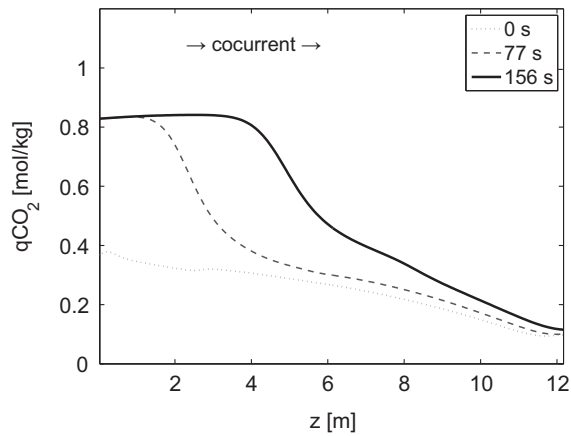

e

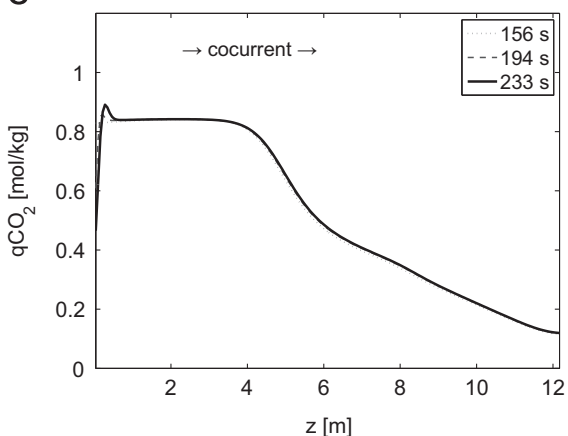

$\mathrm{h}$

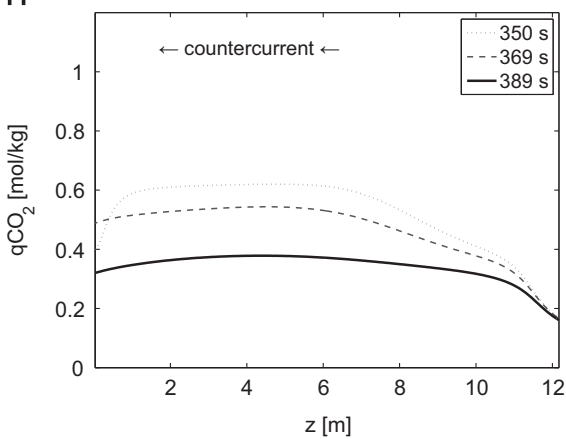

$\mathrm{k}$

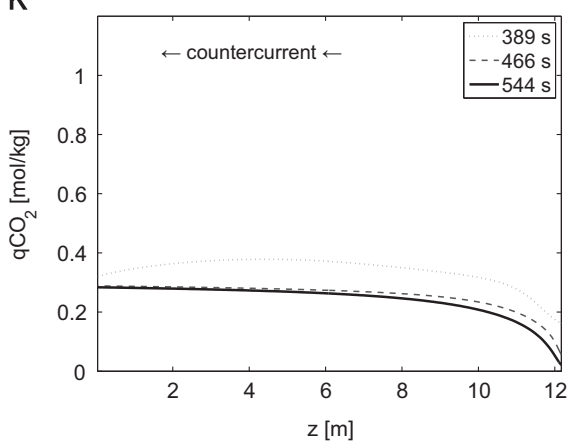

C

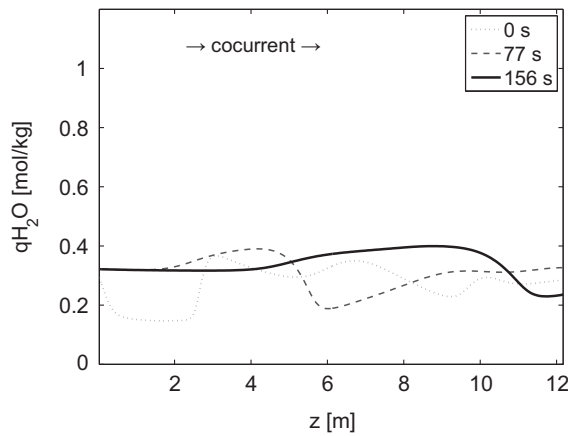

$f$

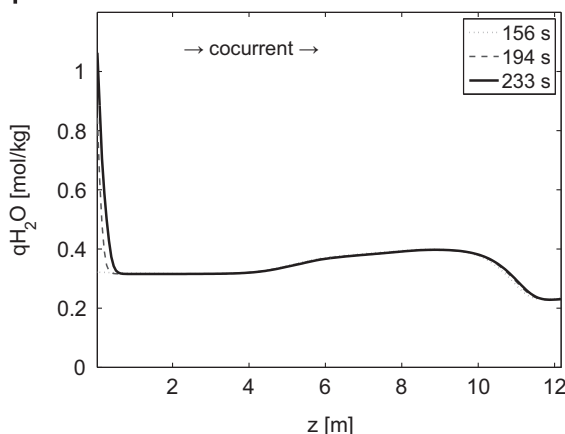

i

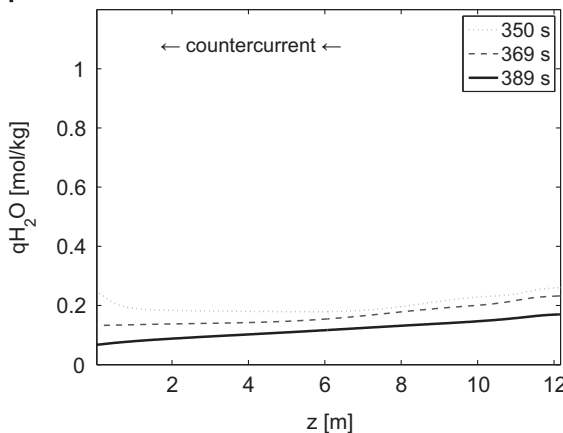

I

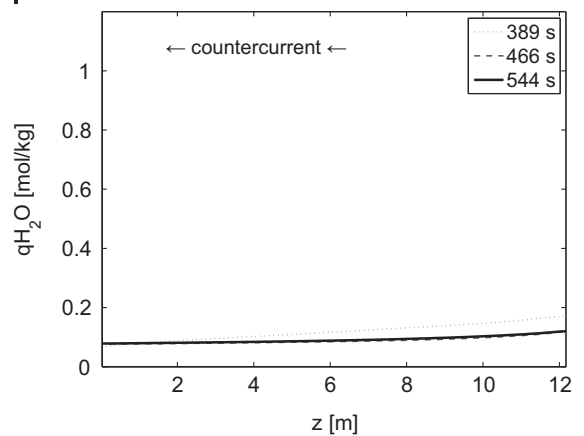

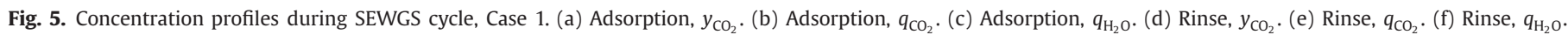
(g) Depressurisation, $y_{\mathrm{CO}_{2}}$. (h) Depressurisation, $q_{\mathrm{CO}_{2}}$. (i) Depressurisation, $q_{\mathrm{H}_{2} \mathrm{O}} \cdot$ (j) Purge, $y_{\mathrm{CO}_{2}}$. (k) Purge, $q_{\mathrm{CO}_{2}}$. (l) Purge, $q_{\mathrm{H}_{2} \mathrm{O}}$.

increasing the steam partial pressure from 7.3 bar in the feed to 24 bar in the rinse. A significant amount of steam is adsorbed, severely limiting the progress of the $\mathrm{H}_{2} \mathrm{O}$ front in the column. During the subsequent pressure equalisations, however, the column pressure decreases and significant amounts of the adsorbed $\mathrm{CO}_{2}$ and $\mathrm{H}_{2} \mathrm{O}$ are released as can be seen from the adsorbed concentrations at the start of the depressurisation. Remarkably, little of the $\mathrm{CO}_{2}$ released has been transferred to another column during the pressure equalisation steps. Rather, it has been readsorbed further downstream in the column. This, of course, is an important precondition in order to achieve a high carbon capture ratio during the next cycle. Finally, the bulk of the $\mathrm{CO}_{2}$ desorbs and the product $\mathrm{CO}_{2}$ is collected during the depressurisation and purge steps that follow. The majority of the $\mathrm{CO}_{2}$ is recovered during depressurisation. During the steam purge still more $\mathrm{CO}_{2}$ desorbs, and is largely recovered as $\mathrm{CO}_{2}$ product, although significant 


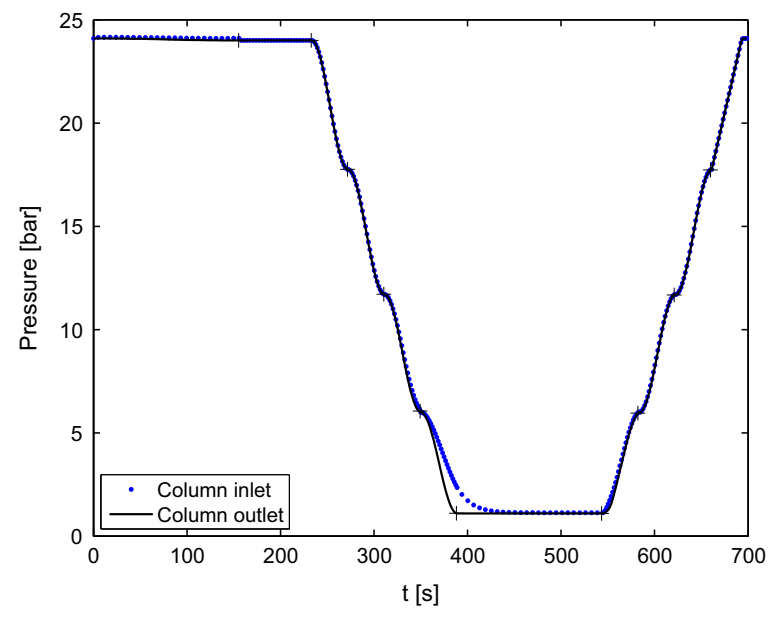

Fig. 6. Column pressure development over the 11-step SEWGS cycle, Case 1.

amounts of $\mathrm{CO}_{2}$ remain both in the gas phase and adsorbed. However, the top of the column is well cleaned, with $q_{\mathrm{CO}_{2}} \rightarrow 0$. In the following steps, pressure equalisations (without $\mathrm{CO}_{2}$, as explained above) and repressurisation with $\mathrm{H}_{2}$ product leave the top of the column free from $\mathrm{CO}_{2}$ while building up the pressure in the column. $\mathrm{CO}_{2}$ that was still adsorbed at the end of the purge step remains adsorbed. The gas phase concentration and solid loading at the start of the adsorption step show that the increasing pressure causes readsorption of the $\mathrm{CO}_{2}$ from the gas phase. The top of the column remains $\mathrm{CO}_{2}$ lean, and $\mathrm{H}_{2}$ can be produced again in the adsorption step at a high carbon capture ratio. So, the purge steam effectively functions to free the top part of the column from $\mathrm{CO}_{2}$, allowing to maintain a high carbon capture ratio. Except for the depressurisation and the start of the purge step, there is no significant pressure drop over the column (Fig. 6).

\subsubsection{Cycle performance}

The single column performance, discussed in the previous section, forms the basis for the performance of the 9 column SEWGS train. In terms of feed and product streams, a single column operates in transient mode. Nine columns in parallel, however, always have 2 columns in adsorption and in purge (Fig. 3). Continuous streams of $\mathrm{H}_{2}$ and $\mathrm{CO}_{2}$ are being produced. Nevertheless, transients remain because of the depressurisation and repressurisation steps. These transients need to be resolved for downstream processes (specifically the gas turbine section), which can be done by buffering (using gas storage tanks or 'surge tanks' Tondeur and Wankat, 1985; Yang, 1987; Sircar, 1988). Note that volumes in externals, piping, etc. (that would cause backmixing and buffering to some extent) are not accounted for in the simulations. The performance of the SEWGS cycle is expressed in terms of the time average $\mathrm{CO}_{2}$ capture rate, $\mathrm{CO}_{2}$ purity, and productivity required for achieving $95 \%$ carbon capture ratio and $99 \% \mathrm{CO}_{2}$ purity. The cycle performance data are further discussed in Section 3.2.

\subsubsection{Implications of an adsorptive rinse}

In the simulation of the SEWGS process, the underlying isotherm model is of critical importance. The current work uses a newly developed binary adsorption isotherm for the competitive adsorption of $\mathrm{CO}_{2}$ and $\mathrm{H}_{2} \mathrm{O}$ on K-HTC, measured up to 24 bar partial pressure. Two aspects are new, therefore, the high pressure part of the isotherm and the effect of competitive adsorption (cf. Boon et al., 2014). Indeed, as shown in Fig. 5, both $\mathrm{CO}_{2}$ and $\mathrm{H}_{2} \mathrm{O}$ adsorb and desorb throughout the SEWGS cycle. Especially during the rinse, a very high solid loading of $\mathrm{H}_{2} \mathrm{O}$ prevails near the column entrance. At the same time, $\mathrm{CO}_{2}$ is partially desorbed and displaced, exhibiting a small roll-up effect as discussed in Section 3.1.1.

In order to assess the effect of the rinse, an additional simulation was performed replicating the Case 1 simulation discussed above but without the adsorption of $\mathrm{H}_{2} \mathrm{O}\left(q_{\mathrm{H}_{2} \mathrm{O}}=0, A_{\mathrm{H}_{2} \mathrm{O}}=0\right)$. Fig. 7 shows the evolution of the concentration of impurities $\left(\mathrm{N}_{2}, \mathrm{CO}, \mathrm{H}_{2}\right.$, $\mathrm{Ar}$ ) at the end of the rinse step and at the end of the subsequent pressure equalisation steps, with and without steam adsorption. When no steam is adsorbed, the $\mathrm{CO}_{2}$ concentration profile is already displaced in the rinse step. However, during the subsequent pressure equalisation steps, the gas phase is not displaced as efficiently as in the base case: the $\mathrm{CO}_{2}$ profile in the column at the start of the depressurisation is more disperse in the case without $\mathrm{H}_{2} \mathrm{O}$ adsorption. In other words, when the steam does not adsorb, the rinse steam mixes with the gas phase in the column, thereby diminishing its own effectiveness. Indeed, the advantage of using an adsorptive rinse to produce two high purity products by PSA has been discussed already in the 1970s. Cen and Yang (1986) have studied the separation of $\mathrm{H}_{2} / \mathrm{CH}_{4}$ by adsorption on activated carbon and were able to obtain both products at over 99\% purity, using recompressed $\mathrm{CH}_{4}$ product as an adsorptive rinse.

The concentration profiles in Fig. 7 confirm the advantage of steam sorption in the efficiency of the rinse. The effect on the overall performance of the cycle is shown in Table 5. The simulation without steam adsorption has a somewhat higher carbon capture ratio, but a much lower $\mathrm{CO}_{2}$ purity. The somewhat higher capture ratio is due to a slightly more efficient regeneration of the sorbent, shown in Fig. 8, leading to the cases with and without $\mathrm{H}_{2} \mathrm{O}$ adsorption to start the adsorption step with an average amount of $\mathrm{CO}_{2}$ adsorbed of $0.25 \mathrm{~mol} \mathrm{~kg}^{-1}$ and $0.23 \mathrm{~mol} \mathrm{~kg}^{-1}$, respectively. These results clearly confirm the benefits of an adsorptive rinse.

For SEWGS, analogously, recompressed $\mathrm{CO}_{2}$ product could be employed as rinse gas as an alternative for $\mathrm{a}_{2} \mathrm{O}$ rinse, given the fact that $\mathrm{CO}_{2}$ also adsorbs. Such a $\mathrm{CO}_{2}$ rinse was proposed by Allam et al. (2005). High pressure $\mathrm{CO}_{2}$ is available from the compression section in a CCS plant. A more thorough evaluation of the potential of the $\mathrm{CO}_{2}$ rinse cycle is currently being performed.

\subsubsection{Implications of the linear driving force mass transfer coefficient}

The present study uses the linear driving force model for simulating the intraparticle mass transfer resistances. The model has been derived and validated previously (Boon et al., 2014), both for adsorption as well as desorption, based on breakthrough and regeneration measurements, respectively. Nevertheless, the results of the current cycle simulations present such a marked decrease in the steam requirement compared to literature studies, partly due to the new linear driving force coefficient, that a further discussion is justified.

The linear driving force model and mass transfer coefficient (Table 2) have values in the range of $0.02-0.3 \mathrm{~s}^{-1}$, varying mainly with the slope of the adsorption isotherm $\left(\partial q_{i} / \partial c_{i}\right)$. The value of $k_{\mathrm{LDF}}$ at the end of adsorption, rinse, depressurisation, and purge steps in Case 1 is shown in Fig. 9, indicating the most important variations. In earlier studies, a lower, and constant value was used. van Selow et al. (2009a) derived a constant linear driving force mass transfer coefficient of $0.03 \mathrm{~s}^{-1}$ for similar operating conditions and particle size. Its value was calculated by matching model predictions to experimental SEWGS cycle performance data with $\mathrm{CO}_{2}$ or $\mathrm{H}_{2} \mathrm{O}$ rinse. Although this approach provided an important first assessment of the intraparticle mass transfer, a recently derived linear driving force relation provides a more realistic description (Boon et al., 2014). Fig. 9 shows that the current 
a

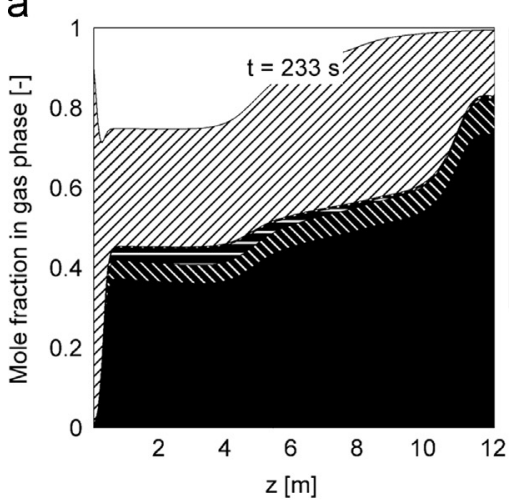

C

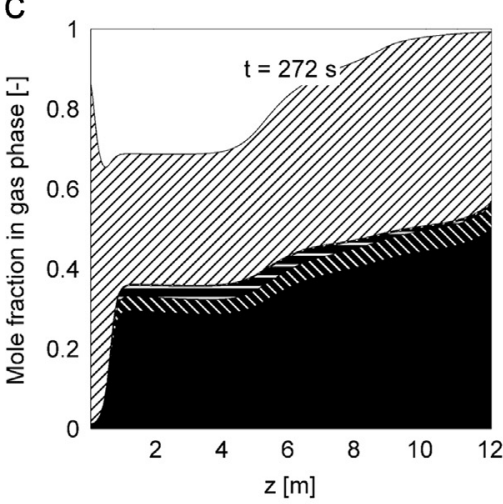

e

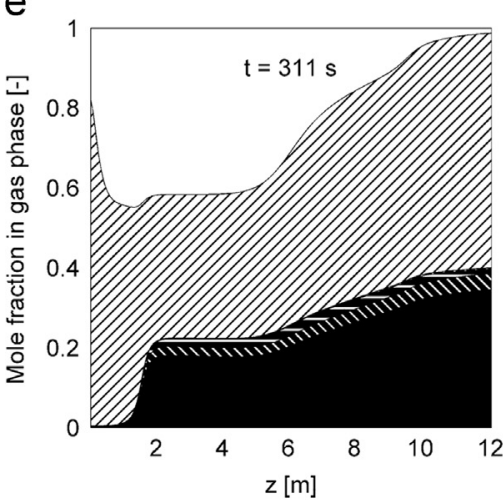

g

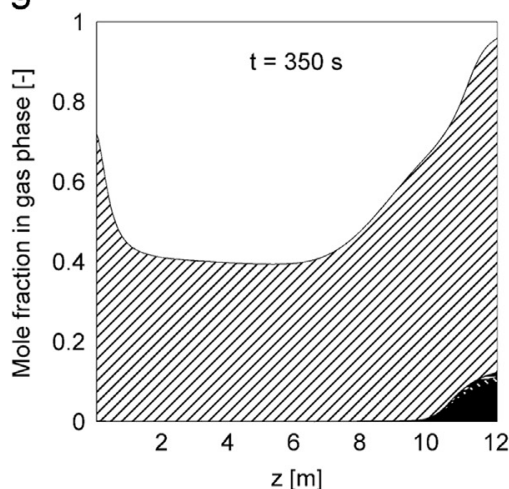

b
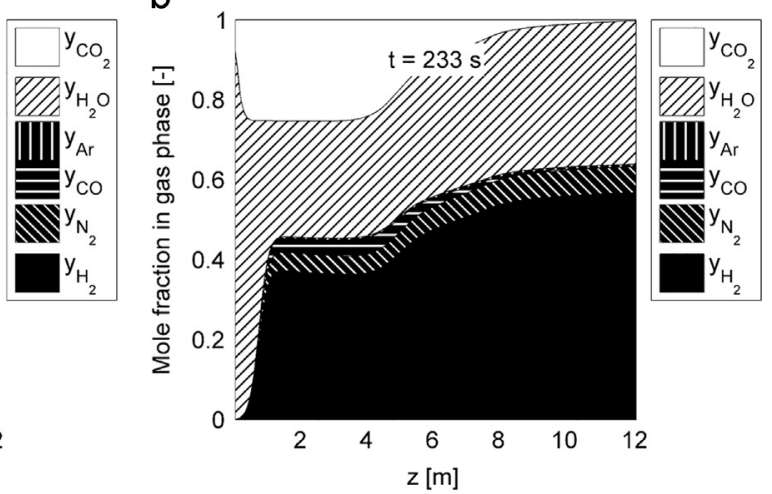

d
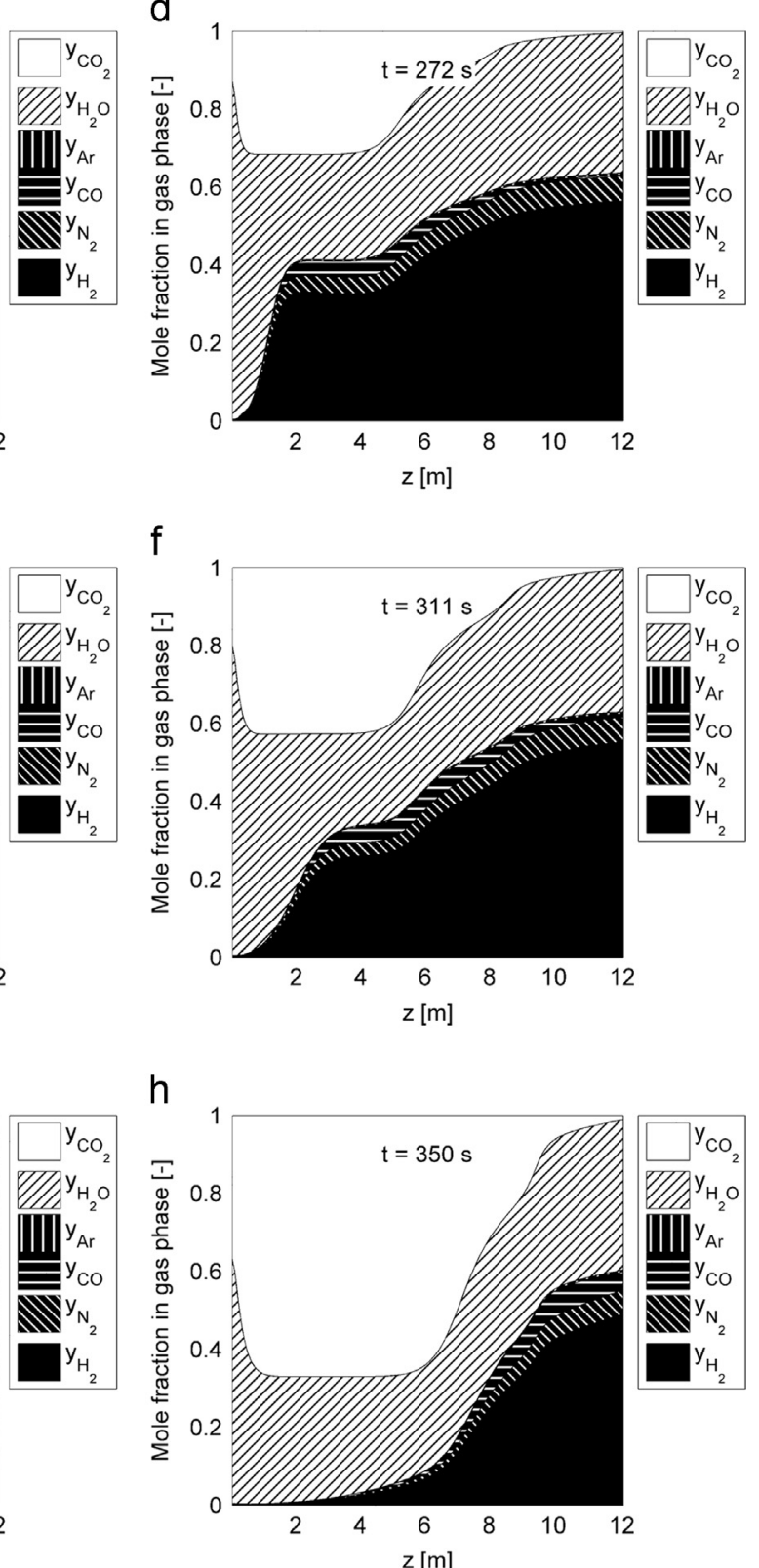

$\mathrm{h}$

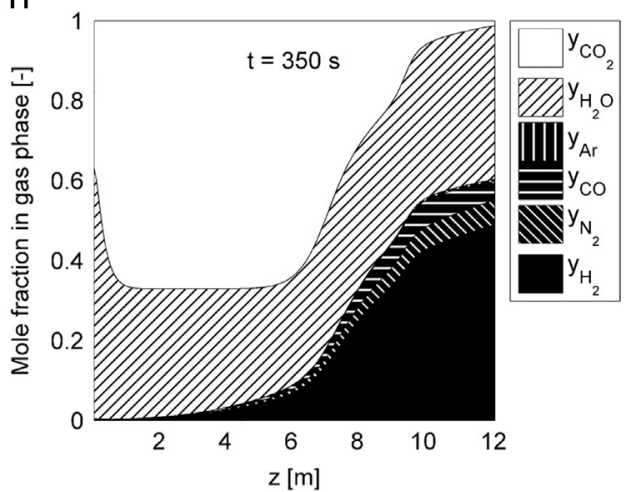

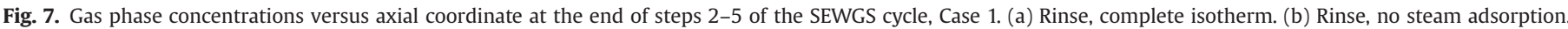

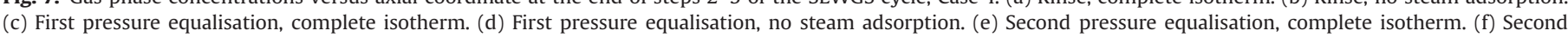
pressure equalisation, no steam adsorption. (g) Third pressure equalisation, complete isotherm. (h) Third pressure equalisation, no steam adsorption. 
validated model predicts a significantly larger linear driving force intraparticle mass transfer coefficient for nearly the entire cycle.

The sensitivity of the system for the value of $k_{\mathrm{LDF}}$ was investigated by running the Case 1 simulation also with increased and reduced values through a pre-factor in the range of $0.1-2$. To some extent, this represents the uncertainty in physical parameters that constitute $k_{\mathrm{LDF}}$, i.e. the intraparticle porosity and tortuosity, pore diameter, and isotherm. However, the linear driving force model has been validated against experimental data, both for breakthrough and regeneration (Boon et al., 2014) and the uncertainty in $k_{\mathrm{LDF}}$ is therefore not very high. Rather, the range of variation of the pre-factor has been significantly extended in order have a more pronounced response. The values for $\mathrm{CO}_{2}$ and $\mathrm{H}_{2} \mathrm{O}$ were both modified simultaneously. Results are shown in Fig. 10. Interestingly, the $\mathrm{CO}_{2}$ product purity is only slightly affected by the value of $k_{\mathrm{LDF}}$. The separation between $\mathrm{CO}_{2}$ and impurities during the rinse and subsequent pressure equalisations becomes slightly more disperse and consequently less effective. But the profiles were fairly sharp and the separation remains good. The capture ratio, in contrast, is very sensitive towards the value of $k_{\mathrm{LDF}}$. Fig. 11 shows the effect of the pre-factor on the $\mathrm{CO}_{2}$ loading profiles in the column at the end of the adsorption and purge steps. Firstly, during the purge, the regeneration of the column becomes less effective, especially near the top of the column (12.2 m). More $\mathrm{CO}_{2}$ remains at the top of the column that will increase the $\mathrm{CO}_{2}$ slip to the $\mathrm{H}_{2}$ product stream. Secondly, during the feed step, the lower value of $k_{\mathrm{LDF}}$ causes the $\mathrm{CO}_{2}$ profile in the column to become more disperse as well. Again, the consequence is a higher $\mathrm{CO}_{2}$ slip to the $\mathrm{H}_{2}$ product. An improved intraparticle mass transfer coefficient will thus lead to a lower purge steam consumption.

\subsection{Parameter study}

Starting from the cases outlined above, a series of 62 simulations was done for $200-750 \mathrm{~s}$ cycle time, $\mathrm{S} / \mathrm{C}_{\text {rinse }} 0.001-0.5$, and $\mathrm{S} / \mathrm{C}_{\text {purge }}$ $0.001-2$. Each of the conditions yields a cyclic steady state with carbon capture ratio and $\mathrm{CO}_{2}$ purity values. The cycles had a carbon

Table 5

Cycle performance for Case $1\left(700 \mathrm{~s}, \mathrm{~S} / \mathrm{C}_{\text {rinse }}=0.06, \mathrm{~S} / \mathrm{C}_{\text {purge }}=0.1\right)$.

\begin{tabular}{llll}
\hline SEWGS cycle & Productivity & $\begin{array}{l}\text { Carbon capture } \\
\text { ratio } \\
\left(\mathrm{mol} \mathrm{mol}^{-1}\right)\end{array}$ & $\mathrm{CO}_{2}$ purity \\
$\left(\mathrm{mol} \mathrm{mol}^{-1}\right)$
\end{tabular}

a

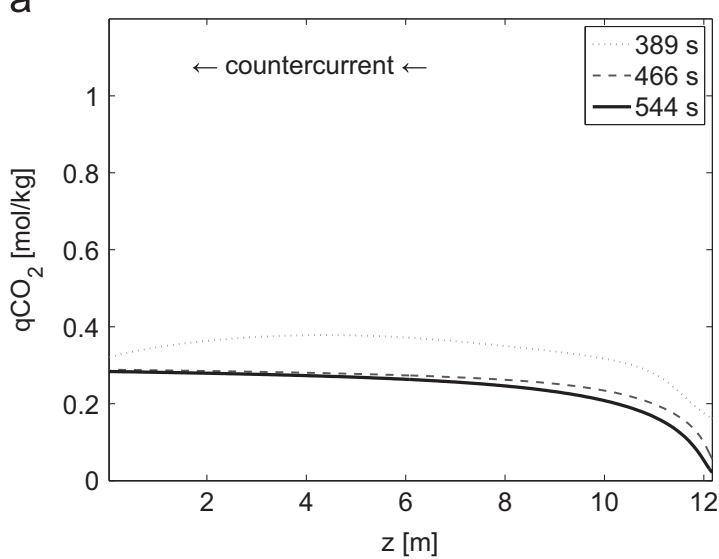

capture ratio in the range of $85-100 \%$, and a $\mathrm{CO}_{2}$ purity in the range of $62-100 \%$, causing the productivity to be in the range of $1.5-$ $1.7 \mathrm{~mol} \mathrm{~kg}^{-1} \mathrm{hr}^{-1}$ and a cyclic working capacity of $0.32 \mathrm{~mol} \mathrm{~kg}{ }^{-1}$. The total steam consumption $\left(S / C_{\text {rinse }}+S / C_{\text {purge }}\right)$ was varied between 0.4 and 43. Using generalised linear regression (Matlab 8.1), two quadratic equations are fitted to $-\log (1-\mathrm{CCR})$ and $-\log (1-\mathrm{CP})$

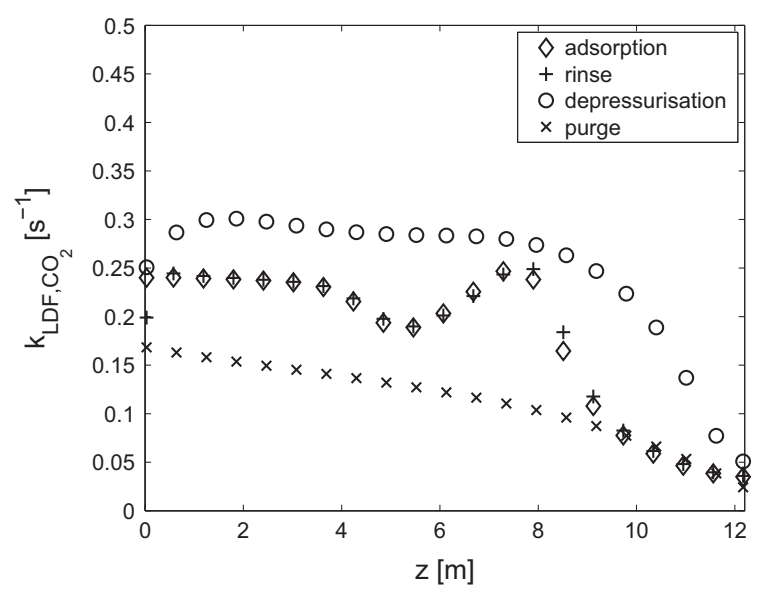

Fig. 9. Linear driving force mass transfer coefficient for $\mathrm{CO}_{2}$ in Case 1 at the end of adsorption, rinse, depressurisation, and purge steps.

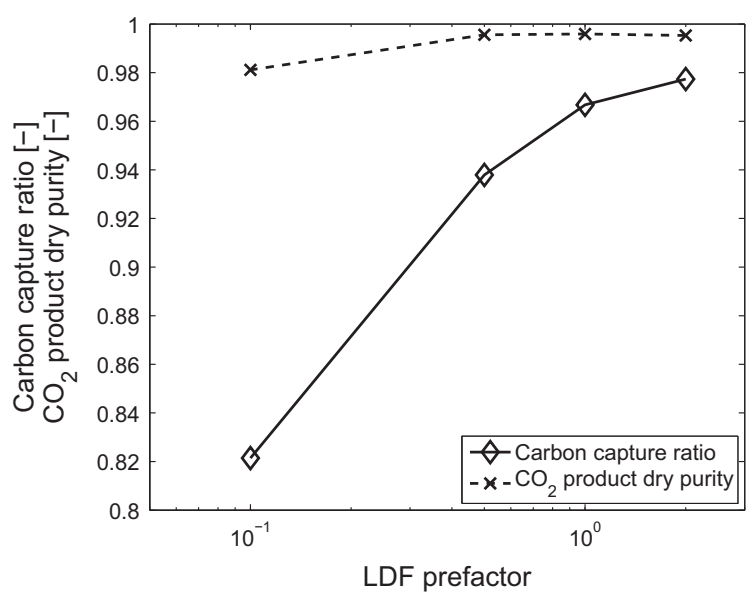

Fig. 10. Cycle performance versus $k_{\mathrm{LDF}}$ pre-factor for SEWGS cycle Case 1.

b

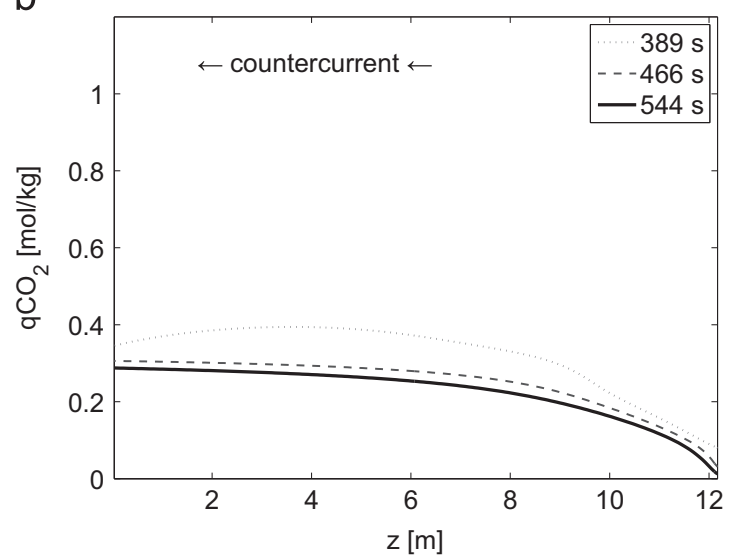

Fig. 8. $\mathrm{CO}_{2}$ loading $q_{\mathrm{CO}_{2}}$ during purge with and without steam adsorption, Case 1. (a) Complete isotherm. (b) No steam adsorption. 
from the simulation results. The trends described by the equations are depicted in Fig. 12.

The trends in Fig. 12 clearly show that the carbon capture ratio is mainly determined by the $S / C_{\text {purge }}$ : an increase in $S / C_{\text {purge }}$ leads to an increase in carbon capture ratio. This is caused by the fact that the purge flow rate determines the extent to which the column is cleaned during the purge step and consequently the amount of $\mathrm{CO}_{2}$ captured in the subsequent adsorption step. Indeed, the same trend has been reported earlier by Reijers et al. (2011) and Jansen et al. (2013). There is a slight opposite trend with $S / C_{\text {rinse, }}$ an increase of which causes the carbon capture ratio to decrease slightly. This also corresponds to the trends reported by Reijers et al. (2011). By feeding more rinse gas to the column, the chance increases of $\mathrm{CO}_{2}$ being carried over during pressure equalisation to the top of the receiving column (see Fig. 1). It will then end up in the $\mathrm{H}_{2}$ product, effectively lowering the carbon capture ratio. Fig. 12b shows that the $\mathrm{CO}_{2}$ purity is determined by $S / C_{\text {rinse, }}$ in line with Reijers et al. (2011) and Jansen et al. (2013). An increase in $S / C_{\text {rinse }}$ causes more syngas to be removed from the column during the rinse and the pressure equalisation steps and consequently increases the $\mathrm{CO}_{2}$ purity. Conversely, decreasing or even omitting rinse will decrease the $\mathrm{CO}_{2}$ purity. An increase in $\mathrm{S} / \mathrm{C}_{\text {purge }}$, on the other hand, leads to a slight decrease in $\mathrm{CO}_{2}$ purity, similar to the trend reported by Reijers et al. (2011). In contrast, Jansen et al. (2013) have observed an increase in $\mathrm{CO}_{2}$ purity with $\mathrm{S} / \mathrm{C}_{\text {purge. }}$ The difference might be caused by the kinetics of desorption. All else being equal, and provided desorption kinetics is sufficiently fast, an increase in $\mathrm{S} / \mathrm{C}_{\text {purge }}$ will lead to a $\mathrm{CO}_{2}$ leaner

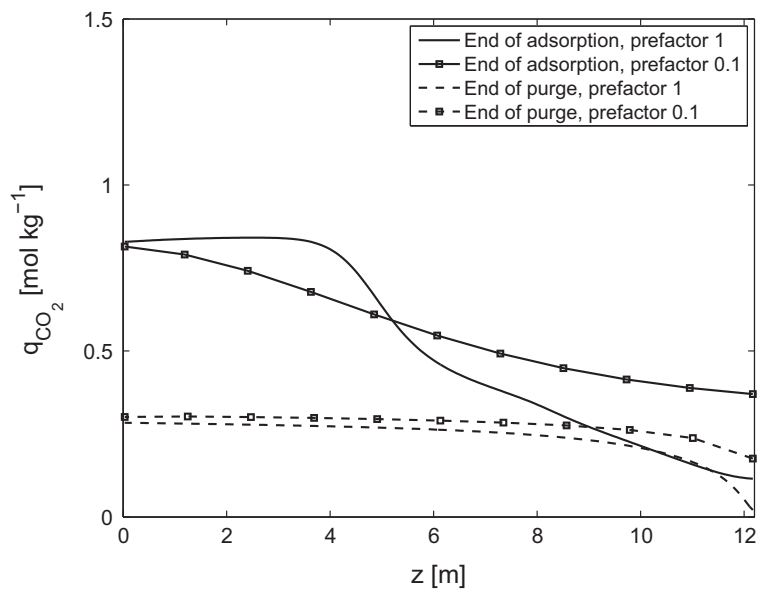

Fig. 11. $\mathrm{CO}_{2}$ loading profiles for $k_{\mathrm{LDF}}$ pre-factor 1 and 0.1 for SEWGS cycle Case 1. sorbent at the start of the adsorption step. With a leaner sorbent, and given the amount of syngas fed in the adsorption step, the $\mathrm{CO}_{2}$ front will progress much less far into the column. Consequently, the column will contain more $\mathrm{H}_{2}$ product gas at the end of the adsorption step and the start of the rinse, resulting in a lower $\mathrm{CO}_{2}$ purity. In contrast, if desorption kinetics is slower, the $q_{\mathrm{CO}_{2}}$ profile in the column will be more homogeneous (flat) throughout the column at the start of the adsorption step (compared to the current process, see Fig. $5 \mathrm{k}$ and $\mathrm{b}$ ). The adsorption step will then have a less steep front and syngas will be present in a larger part of the column at the start of the rinse, already decreasing the $\mathrm{CO}_{2}$ purity. In such a case, using more purge gas will improve the extent to which the column is regenerated near the $\mathrm{H}_{2}$ product side of the column. This then causes a better separation during the adsorption, rinse, and pressure equalisation steps. The $\mathrm{CO}_{2}$ purity is then improved by increasing $S / C_{\text {purge. }}$. Fig. 12 shows that purge as well as rinse are required to achieve the targets for carbon capture ratio and $\mathrm{CO}_{2}$ purity. In conclusion, the amount of rinse steam effectively determines the $\mathrm{CO}_{2}$ purity and the amount of purge steam effectively determines the carbon capture ratio, they are determined independently by the targets of $99 \% \mathrm{CO}_{2}$ purity and 95\% carbon capture ratio.

Fig. 13 shows the response of the SEWGS cycle to variations in the total cycle time, leaving the relative duration of each step and the feed flow rate unchanged (according to Table 4). The more syngas is fed due to the longer cycle time, the more $\mathrm{CO}$ and $\mathrm{CO}_{2}$ slip through into the $\mathrm{H}_{2}$ product during the adsorption step. The longer time for purge will provide a leaner sorbent but not to such an
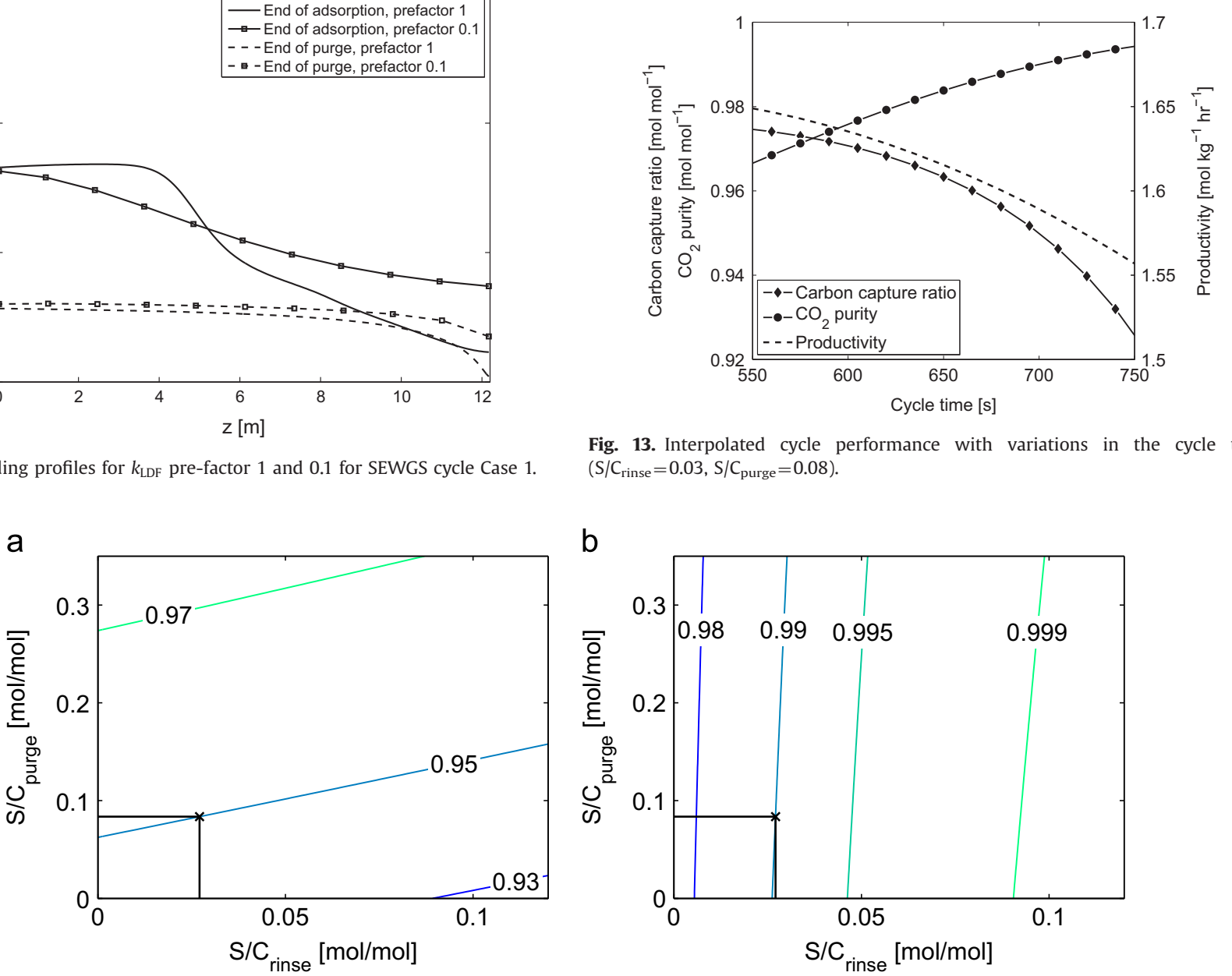

Fig. 13. Interpolated cycle performance with variations in the cycle time $\left(\mathrm{S} / \mathrm{C}_{\text {rinse }}=0.03, \mathrm{~S} / \mathrm{C}_{\text {purge }}=0.08\right)$.

b

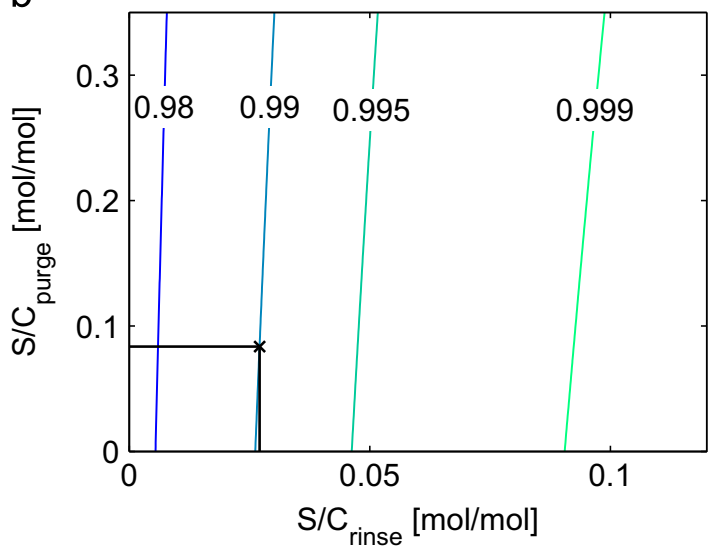

Fig. 12. Interpolated cycle performance versus $S / C_{\text {rinse, }}$ and $S / C_{\text {purge }}$ for a $700 \mathrm{~s} S E W G S$ cycle. (a) Carbon capture ratio. (b) $\mathrm{CO}_{2}$ purity. 
Table 6

Precombustion $\mathrm{CO}_{2}$ capture by SEWGS compared for an IGCC power plant, net electric efficiency on LHV basis.

\begin{tabular}{|c|c|c|c|c|c|c|}
\hline & $\begin{array}{l}\text { Carbon capture ratio } \\
\%\end{array}$ & $\begin{array}{l}\mathrm{CO}_{2} \text { purity } \\
\%\end{array}$ & $\begin{array}{l}\mathrm{S} / \mathrm{C}_{\text {rinse }} \\
\mathrm{mol} \mathrm{mol}^{-1}\end{array}$ & $\begin{array}{l}\mathrm{S} / \mathrm{C}_{\text {purge }} \\
\mathrm{mol} \mathrm{mol}^{-1}\end{array}$ & $\begin{array}{l}\text { Overall efficiency } \\
\%\end{array}$ & Source \\
\hline No capture & 0 & & & & 47.1 & Gazzani et al. (2013) \\
\hline Selexol & 95 & 99 & & & 36.0 & Gazzani et al. (2013) \\
\hline SEWGS, sorbent alpha & 95 & 99 & 0.44 & 1.06 & 38.5 & Gazzani et al. (2013); Jansen et al. (2013) \\
\hline SEWGS, sorbent beta & 95 & 99 & 0.36 & 0.08 & 39.8 & Gazzani et al. (2013) \\
\hline SEWGS, K-HTC & 95 & 99 & 0.03 & 0.08 & $\mathrm{n} / \mathrm{a}$ & This work \\
\hline SEWGS, K-HTC & 95 & 95 & $0.4-0.65$ & $1.5-1.25$ & $\mathrm{n} / \mathrm{a}$ & Wright et al. (2011) \\
\hline SEWGS, K-HTC & 90 & 98 & 0.55 & 1.3 & $\mathrm{n} / \mathrm{a}$ & Reijers et al. (2011) \\
\hline
\end{tabular}

extent that the slip of additional $\mathrm{CO}$ and $\mathrm{CO}_{2}$ during the adsorption step can be prevented. Consequently, the carbon capture ratio decreases with increasing cycle time. Since less $\mathrm{CO}_{2}$ is produced with the same amount of sorbent, the productivity decreases analogously. The $\mathrm{CO}_{2}$ purity, in contrast, increases with increasing cycle time due to the higher $\mathrm{CO}_{2}$ content and consequently lower concentration of impurities $\left(\mathrm{H}_{2}, \mathrm{~N}_{2}\right)$ in the column at the end of the adsorption step.

Given the currently employed isotherm and linear driving force kinetics (Boon et al., 2014), the model predicts the SEWGS cycle to perform at specified carbon capture ratio and $\mathrm{CO}_{2}$ purity of $95 \%$ and $99 \%$, respectively, with $S / C_{\text {rinse }}$ of 0.03 and $S / C_{\text {purge }}$ of 0.08 indicated by the $\times$ mark in Fig. 12 and a productivity of $1.6 \mathrm{~mol} \mathrm{~kg}^{-1} \mathrm{~h}^{-1}$. As discussed below (see Table 6), this is a marked reduction in the predicted steam consumption compared to available literature data, both for the rinse and the purge. Improvements to the predicted cycle performance are due to the new isotherm and better description of intraparticle mass transfer (Boon et al., 2014), that were discussed above. The isotherm is now extended with high-pressure nanopore adsorption contributing to the capacity of the sorbent as well as the adsorption of steam. Accurate description of the adsorption of steam makes that the rinse now has become an adsorptive rinse, which is known to greatly improve the purity of the bottom product. Indeed, the cycle performance data in Table 6 indicate the large reduction in the amount of rinse gas required when using an adsorptive $\mathrm{H}_{2} \mathrm{O}$ rinse for enhancing the $\mathrm{CO}_{2}$ product purity. At the same time, intraparticle mass transfer is now described using the newly developed and experimentally validated linear driving force relation which leads to a reduction in purge steam consumption. The cycle proposed in the current work needs to be validated experimentally. The fate of $\mathrm{H}_{2} \mathrm{~S}$ in the SEWGS cycle, which is presently assumed to be co-captured with $\mathrm{CO}_{2}$, also needs to be verified.

The present study aimed at finding the optimum operating conditions, as well as important sensitivities, for the proposed 11 step cycle for 9 columns. Other designs are possible, and have been presented in the literature. The $\mathrm{H}_{2} \mathrm{O}$ rinse could be replaced by a $\mathrm{CO}_{2}$ rinse, and repressurisation could be done with syngas instead of $\mathrm{H}_{2}$ product. Given the fact that the steam consumption for the current design is very low, it might be feasible to reduce the number of pressure equalisation steps in the cycle, in order to reduce the required number of columns and CAPEX for the system. An evaluation of these alternatives is currently being performed.

\subsection{System aspects}

The parameter study presented above yields interesting insights in the performance of the SEWGS cycle as a function of steam consumption. It may serve as a valuable starting point for an economic optimisation study, carefully weighing CAPEX and OPEX for SEWGS as precombustion $\mathrm{CO}_{2}$ capture technology. This, however, is beyond the scope of the current study. Nevertheless, it is important to highlight the performance of the currently proposed SEWGS cycle, compared against cycles that were modelled previously. Table 6 shows the performance of several cycles and Selexol as reference technology for precombustion capture of $\mathrm{CO}_{2}$ from an IGCC power plant.

The attainable reduction in steam consumption will significantly improve the economic feasibility. Table 6 shows that sorbent beta lowers the purge steam amount by about the same ratio as found in the current work and the rinse steam amount by about $20 \%$, due only to an increased capacity relative to sorbent alpha (Gazzani et al., 2013), leading to an efficiency improvement of $1.3 \%$-point. The current work indicates a further reduction in rinse steam is possible by properly taking into account the adsorption of steam on the sorbent. A reduction in rinse steam will directly reduce the amount of high pressure steam taken from the power island (Gazzani et al., 2013) and consequently yield a significant improvement in the overall efficiency.

With the gain in efficiency that is currently predicted for SEWGS, the process may become interesting for industrial $\mathrm{H}_{2}$ production as well. This is something that needs to be assessed through economic studies. In addition, the newly predicted cycle performance figures might put the feasibility of SEWGS for precombustion $\mathrm{CO}_{2}$ capture in NGCC in a new perspective, provided that the enhanced efficiency outweighs the additional investment (cf. Manzolini et al., 2013b).

\section{Conclusion}

In this paper, a pressure swing cycle is proposed for the sorptionenhanced water-gas shift (SEWGS) process. The proposed cycle has been developed based on a recently developed isotherm for competitive adsorption of $\mathrm{CO}_{2}$ and $\mathrm{H}_{2} \mathrm{O}$ on potassium-promoted hydrotalcite. It has been shown that co-adsorption of steam during the SEWGS cycle is beneficial for the efficiency of the rinse step. A parameter study based on numerical simulations has yielded a SEWGS cycle that consumes significantly less steam than previously reported cycle designs in the literature.

\section{Nomenclature}

A nanopore-sorbate interaction parameter, dimensionless

$a_{\mathrm{p}} \quad$ particle interfacial area per unit volume, $\mathrm{m}^{-1}$

CCR carbon capture ratio, $\mathrm{CO}_{2}$ in $\mathrm{CO}_{2}$ product divided by $\mathrm{CO}$ and $\mathrm{CO}_{2}$ in feed, mol mol${ }^{-1}$

$\mathrm{CP} \quad \mathrm{CO}_{2}$ product purity, $\mathrm{mol} \mathrm{mol} \mathrm{m}^{-1}$

$C_{p, \mathrm{p}} \quad$ particle heat capacity, $\mathrm{J} \mathrm{kg}^{-1} \mathrm{~K}^{-1}$

$C_{p} \quad$ gas heat capacity, $\mathrm{J} \mathrm{kg}^{-1} \mathrm{~K}^{-1}$

$d_{\mathrm{p}} \quad$ particle diameter, $\mathrm{m}$

$d_{\mathrm{c}} \quad$ column internal diameter, $\mathrm{m}$

$D_{z} \quad$ axial mass dispersion coefficient, $\mathrm{m}^{2} \mathrm{~s}^{-1}$

$\mathcal{D}_{\mathrm{p}} \quad$ effective intraparticle molar diffusion coefficient, $\mathrm{m}^{2} \mathrm{~s}^{-1}$

E nanopore-sorbate interaction energy, $\mathrm{J} \mathrm{mol}^{-1}$

$f \quad$ friction factor, dimensionless

$F \quad$ molar flow rate, mol s$^{-1}$ 
$F_{\mathrm{m}} \quad$ mass flow rate, $\mathrm{mol} \mathrm{s}^{-1}$

$\Delta H_{\mathrm{a}} \quad$ adsorption enthalpy, $\mathrm{J} \mathrm{mol}^{-1}$

$\Delta H_{\mathrm{r}} \quad$ reaction enthalpy water-gas shift, $\mathrm{J} \mathrm{mol}^{-1}$

$i \quad$ species index, dimensionless

$K \quad$ surface-sorbate interaction parameter, $\mathrm{Pa}^{-1}$

$k_{\mathrm{LDF}} \quad$ linear driving force intraparticle mass transfer coefficient, $\mathrm{s}^{-1}$

M molar mass, $\mathrm{kg} \mathrm{mol}^{-1}$

$m$ pore-size distribution parameter, dimensionless

$n \quad$ Freundlich isotherm parameter, dimensionless

$N \quad$ molar flux, mol m $\mathrm{m}^{-2} \mathrm{~s}^{-1}$

$N \quad$ total number of species, dimensionless

$p \quad$ pressure, $\mathrm{Pa}$

$p_{c} \quad$ critical pressure, $\mathrm{Pa}$

$p_{0} \quad$ saturation pressure, extrapolated to $T>T_{\mathrm{c}}$, Pa

$q \quad$ excess amount adsorbed, $\mathrm{mol} \mathrm{kg}^{-1}$

$q^{\text {eq }} \quad$ equilibrium amount adsorbed, $\mathrm{mol} \mathrm{kg}^{-1}$

$q^{s} \quad$ maximum(monolayer) amount adsorbed, mol kg-1

$R \quad$ gas constant, $\mathrm{J} \mathrm{mol}^{-1} \mathrm{~K}^{-1}$

$r_{\text {WGS }} \quad$ water-gas shift reaction rate, $\mathrm{mol} \mathrm{kg}^{-1} \mathrm{~s}^{-1}$

$T$ temperature, $\mathrm{K}$

$t$ time, s

$t_{\mathrm{e}} \quad$ time of complete breakthrough, $\mathrm{s}$

$T_{\mathrm{c}} \quad$ critical temperature, $\mathrm{K}$

$T_{\mathrm{w}} \quad$ wall temperature, $\mathrm{K}$

$U$ overall heat transfer coefficient, $\mathrm{W} \mathrm{m}^{-2} \mathrm{~K}^{-1}$

$u \quad$ superficial gas velocity, $\mathrm{m} \mathrm{s}^{-1}$

$v \quad$ interstitial gas velocity, $\mathrm{m} \mathrm{s}^{-1}$

$v_{\mathrm{m}} \quad$ molar volume, $\mathrm{cm}^{3} \mathrm{~mol}^{-1}$

$V_{0} \quad$ limiting nanopore volume per mass of sorbent, $\mathrm{cm}^{3} \mathrm{~kg}^{-1}$

$y_{i} \quad$ mole fraction of species $i$, dimensionless

$z \quad$ axial coordinate, $\mathrm{m}$

Greek

$\epsilon_{\mathrm{b}} \quad$ bed porosity, dimensionless

$\lambda \quad$ axial thermal conductivity, $\mathrm{W} \mathrm{m}{ }^{-1} \mathrm{~K}^{-1}$

$\omega \quad$ mass fraction, dimensionless

$\rho \quad$ gas density, $\mathrm{kg} \mathrm{m}^{-3}$

$\rho_{\mathrm{p}} \quad$ particle density, $\mathrm{kg} \mathrm{m}^{-3}$

\section{Abbreviations}

CAPEX capital expenditure

HTC hydrotalcite

IGCC integrated gasification combined cycle

K-HTC potassium-promoted hydrotalcite

OPEX operational expenditure

PSA pressure swing adsorption

$S / C_{\text {rinse }}$ rinse steam to carbon feed ratio, $\mathrm{mol} \mathrm{mol}^{-1}$

$S / C_{\text {purge }}$ purge steam to carbon feed ratio, $\mathrm{mol} \mathrm{mol}^{-1}$

SEWGS sorption-enhanced water-gas shift

WGS water-gas shift

\section{Acknowledgement}

Part of this research has been carried out in the context of the CATO-2 programme. CATO-2 is the Dutch national research programme on $\mathrm{CO}_{2}$ Capture and Storage technology (CCS). The programme is financially supported by the Dutch government (Ministry of Economic Affairs) and the industrial CATO-2 consortium parties.

\section{References}

Allam, R.J., Chiang, R., Hufton, J.R., Middleton, P., Weist, E.L., White, V., 2005. Chapter 13-development of the sorption enhanced water gas shift process. In:
Thomas, D.C. (Ed.), Carbon Dioxide Capture for Storage in Deep Geologic Formations. Elsevier Science, Amsterdam, pp. 227-256. http://dx.doi.org/10. 1016/B978-008044570-0/50099-4.

Bird, R.B., Stewart, W.E., Lightfoot, E.N., 1960. Transport Phenomena. Wiley, New York.

Birol, F., 2013. World Energy Outlook Special Report 2013: Redrawing the Energy Climate Map. IEA, Paris.

Boon, J., Cobden, P.D., van Dijk, H.A.J., Hoogland, C., van Selow, E.R., van Sint Annaland, M., 2014. Isotherm model for high-temperature, high-pressure adsorption of $\mathrm{CO}_{2}$ and $\mathrm{H}_{2} \mathrm{O}$ on K-promoted hydrotalcite. Chem. Eng. J. 248 , 406-414. http://dx.doi.org/10.1016/j.cej.2014.03.056.

Cen, P.L., Yang, R.T., 1986. Separation of binary gas mixture into two high-purity products by a new pressure swing adsorption cycle. Sep. Sci. Technol. 21, 845-864. http://dx.doi.org/10.1080/01496398608058382.

Chemische Fabrik Griesheim-Elektron, 1915. Hydrogen. Patent DE284816.

Van Dijk, H.A.J., Walspurger, S., Cobden, P.D., van den Brink, R.W., de Vos, F.G., 2011. Testing of hydrotalcite-based sorbents for $\mathrm{CO}_{2}$ and $\mathrm{H}_{2} \mathrm{~S}$ capture for use in sorption enhanced water gas shift. Int. J. Greenh. Gas Control 5, 505-511. http://dx.doi.org/10.1016/j.ijggc.2010.04.011.

Ebner, A.D., Reynolds, S.P., Ritter, J.A., 2007. Nonequilibrium kinetic model that describes the reversible adsorption and desorption behavior of $\mathrm{CO}_{2}$ in a K-promoted hydrotalcite-like compound. Ind. Eng. Chem. Res. 46, 1737-1744.

Gazzani, M., Macchi, E., Manzolini, G., 2013. $\mathrm{CO}_{2}$ capture in integrated gasification combined cycle with SEWGS-Part A: thermodynamic performances. Fuel 105, 206-219. http://dx.doi.org/10.1016/j.fuel.2012.07.048.

Gluud, W., Keller, K., Schonfelder, R., Klempt, W., 1931. Production of hydrogen.

Gülker, F., 1927. Production of hydrogen (Herstellung von Wasserstoff). Patent DE446488 (GB) (US1816523).

Hufton, J.R., Mayorga, S., Sircar, S., 1999. Sorption-enhanced reaction process for hydrogen production. AIChE J. 45, 248-256.

Jansen, D., van Selow, E., Cobden, P., Manzolini, G., Macchi, E., Gazzani, M., Blom, R. Henriksen, P.P., Beavis, R., Wright, A., 2013. SEWGS technology is now ready for scale-up!. Energy Proced. 37, 2265-2273. http://dx.doi.org/10.1016/j. egypro.2013.06.107.

Lee, K.B., Beaver, M.G., Caram, H.S., Sircar, S., 2008. Reversible chemisorbents for carbon dioxide and their potential applications. Ind. Eng. Chem. Res. 47, 8048-8062.

Lee, K.B., Verdooren, A., Caram, H.S., Sircar, S., 2007. Chemisorption of carbon dioxide on potassium-carbonate-promoted hydrotalcite. J. Colloid Interface Sci. 308, 30-39.

Manzolini, G., Macchi, E., Gazzani, M., 2013a. $\mathrm{CO}_{2}$ capture in integrated gasification combined cycle with SEWGS-Part B: economic assessment. Fuel 105, 220-227. http://dx.doi.org/10.1016/j.fuel.2012.07.043.

Manzolini, G., Macchi, E., Gazzani, M., 2013b. $\mathrm{CO}_{2}$ capture in natural gas combined cycle with SEWGS, Part B: economic assessment. Int. J. Greenh. Gas Control 12, 502-509. http://dx.doi.org/10.1016/j.ijggc.2012.06.021.

Marono, M., Torreiro, Y., Gutierrez, L., 2013. Influence of steam partial pressures in the $\mathrm{CO}_{2}$ capture capacity of K-doped hydrotalcite-based sorbents for their application to SEWGS processes. Int. J. Greenh. Gas Control 14, 183-192. http://dx.doi.org/10.1016/j.ijggc.2013.01.024.

Maroño, M., Torreiro, Y., Montenegro, L., Sánchez, J., 2014. Lab-scale tests of different materials for the selection of suitable sorbents for $\mathrm{CO}_{2}$ capture with $\mathrm{H}_{2}$ production in IGCC processes. Fuel 116, 861-870. http://dx.doi.org/10.1016/j. fuel.2013.03.067.

Metz, B., Davidson, O., deConinck, H., Loos, M., Meyer, L. (Eds.), 2005. IPCC Special Report on Carbon Dioxide Capture and Storage. Cambridge University Press, UK. chapter Capture of $\mathrm{CO}_{2}$. pp. 105-178.

Oliveira, E.L.G., Grande, C.A., Rodrigues, A.E., 2008. $\mathrm{CO}_{2}$ sorption on hydrotalcite and alkali-modified ( $\mathrm{K}$ and $\mathrm{Cs}$ ) hydrotalcites at high temperatures. Sep. Purif. Technol. 62, 137-147.

Poling, B.E., Prausnitz, J.M., O'Connell, J.P., 2001. The Properties of Gases and Liquids, 5th ed. McGraw-Hill, New York.

Reijers, R., van Selow, E., Cobden, P., Boon, J., van den Brink, R., 2011. SEWGS process cycle optimization. Energy Proced. 4, 1155-1161. http://dx.doi.org/10.1016/j. egypro.2011.01.168.

Ruthven, D.M., 1984. Principles of Adsorption and Adsorption Processes. WileyInterscience, New York.

van Selow, E.R., Cobden, P.D., van den Brink, R.W., Wright, A., White, V., Hinderink, P. Hufton, J.R., 2009a. Carbon dioxide capture for storage in deep geologic formations. Berks, CPL Press. Chapter. Pilot-scale development of the sorption enhanced water gas shift process. pp. 157-180.

van Selow, E.R., Cobden, P.D., van Dijk, H.A.J., Walspurger, S., Verbraeken, P.A., Jansen, D., 2013. Qualification of the ALKASORB sorbent for the sorptionenhanced water-gas shift process. Energy Proced. 37, 180-189. http://dx.doi. org/10.1016/j.egypro.2013.05.100.

van Selow, E.R., Cobden, P.D., Verbraeken, P.A., Hufton, J.R., van Den Brink, R.W. 2009b. Carbon capture by sorption-enhanced water-gas shift reaction process using hydrotalcite-based material. Ind. Eng. Chem. Res. 48, 4184-4193.

Sircar, S., 1988. Separation of methane and carbon dioxide gas mixtures by pressure swing adsorption. Sep. Sci. Technol. 23, 519-529. http://dx.doi.org/10.1080/ 01496398808057650

Tondeur, D., Wankat, P.C., 1985. Gas purification by pressure swing adsorption. Sep. Purif. Rev. 14, 157-212. http://dx.doi.org/10.1080/03602548508068420.

Toops, T.J., Crocker, M., 2008. New sulfur adsorbents derived from layered double hydroxides: II. DRIFTS study of $\mathrm{COS}$ and $\mathrm{H}_{2} \mathrm{~S}$ adsorption. Appl. Catal. B: Env. 82, 199-207. http://dx.doi.org/10.1016/j.apcatb.2008.01.013. 
Walspurger, S., Boels, L., Cobden, P.D., Elzinga, G.D., Haije, W.G., vandenBrink, R.W., 2008. The crucial role of the $\mathrm{K}^{+}$-aluminium oxide interaction in $\mathrm{K}^{+}$-promoted alumina- and hydrotalcite-based materials for $\mathrm{CO}_{2}$ sorption at high temperatures. ChemSusChem 1, 643-650.

Walspurger, S., Cobden, P.D., Safonova, O.V., Wu, Y., Anthony, E.J., 2010. High $\mathrm{CO}_{2}$ storage capacity in alkali-promoted hydrotalcite-based material: in situ detection of reversible formation of magnesium carbonate. Chem. Eur. J. 16, 12694-12700. http://dx.doi.org/10.1002/chem.201000687.

Walspurger, S., de Munck, S., Cobden, P.D., Haije, W.G., van den Brink, R.W., Safonova O.V., 2011. Correlation between structural rearrangement of hydrotalcite-type materials and $\mathrm{CO}_{2}$ sorption processes under pre-combustion decarbonisation conditions. Energy Proced. 4, 1162-1167. http://dx.doi.org/10.1016/j.egypro.2011. 01.169 .

Wang, Q., Tay, H.H., Guo, Z., Chen, L., Liu, Y., Chang, J., Zhong, Z., Luo, J., Borgna, A., 2012. Morphology and composition controllable synthesis of $\mathrm{Mg}-\mathrm{Al}-\mathrm{CO}_{3}$ hydrotalcites by tuning the synthesis $\mathrm{pH}$ and the $\mathrm{CO}_{2}$ capture capacity. Appl. Clay Sci. 55, 18-26. http://dx.doi.org/10.1016/j.clay.2011.07.024.
Westerterp, K.R., van Swaaij, W.P.M., Beenackers, A.A.C.M., 1987. Chemical Reactor Design and Operation, 2nd ed. Wiley, Chichester.

Wright, A., White, V., Hufton, J., vanSelow, E., Hinderink, P., 2009. Reduction in the cost of pre-combustion $\mathrm{CO}_{2}$ capture through advancements in sorptionenhanced water-gas-shift. Energy Proced. 1, 707-714. http://dx.doi.org/ 10.1016/j.egypro.2009.01.093.

Wright, A.D., White, V., Hufton, J.R., Quinn, R., Cobden, P.D., van Selow, E.R., 2011. Caesar: development of a SEWGS model for IGCC. Energy Proced. 4, 1147-1154.

Wu, Y.J., Li, P., Yu, J.G., Cunha, A.F., Rodrigues, A.E., 2013. K-promoted hydrotalcites for $\mathrm{CO}_{2}$ capture in sorption enhanced reactions. Chem. Eng. Technol. 36, 567-574.

Yang, R.T., 1987. Gas Separation by Adsorption Processes. Imperial College Press, Butterworths, Boston.

Yong, Z., Mata, V., Rodrigues, A.E., 2002. Adsorption of carbon dioxide at high temperature-a review. Sep. Purif. Technol. 26, 195-205. 


\section{ECN}

Westerduinweg 3

P.O. Box 1

1755 LE Petten

1755 LG Petten

The Netherlands

The Netherlands

$\mathrm{T}+31885154949$

$F+31885158338$

info@ecn.nl

www.ecn.nl 